\title{
Efficacy of Andrographis paniculata supplements induce a non-specific immune system against the pathogenicity of Aeromonas hydrophila infection in Indian major carp (Labeo rohita)
}

\author{
Radhakrishnan Palanikani ${ }^{1} \cdot$ Kanagaraj Muthu-Pandian Chanthini $^{1} \cdot$ Ramaiah Soranam $^{1} \cdot$ Annamalai Thanigaivel $^{1}$. \\ Sengodan Karthi ${ }^{1}$ - Sengottayan Senthil-Nathan ${ }^{1}$ (D) - Arunachalam Ganesan Murugesan ${ }^{1}$
}

Received: 29 November 2018 / Accepted: 11 July 2019 / Published online: 30 July 2019

(C) Springer-Verlag GmbH Germany, part of Springer Nature 2019

\begin{abstract}
Aeromonas hydrophila, an opportunistic fish pathogen, which causes several major diseases including skin ulcer and haemorrhagic septicemia, contributes considerably to the lethality in aquaculture. Chemical and antibiotic treatment employed against $A$. hydrophila for disease management are expensive and consequently prompted the advent of drug resistance among the pathogens. To overcome these draw backs, alternative aquatic disease control methods using conventional plant-based medicines are focussed. Our present study aimed to augment the fish non-specific immune system with the implementation of methanolic crude extracts of Andrographis paniculata to Labeo rohita, for evaluating their efficacy against A. hydrophila. Histology of major organs of $A$. hydrophila-infected fish such as the gills and liver displayed severe tissue damage. A. paniculata extracts exhibited the strong antibacterial activity against $A$. hydrophila even at lower concentrations $(50 \mu \mathrm{l})$. The extracts also altered the haematological profile of treated infected fishes by increasing the levels of haemoglobin and total erythrocyte-leucocyte counts, along with the phagocytic index. The extracts also had a significant impact on modifying the anatomy and swimming pattern of infected fish, post treatment with the extracts. Also, A. paniculata treated infected fishes in all the plant extract administration methods, viz. injection, oral feeding and diffusion, and reduced the cumulative mortality rate to less than $30 \%$. Even lower concentrations of $A$. paniculata extracts $(50 \mu \mathrm{l})$ resulted in maximum relative percentage survival of treated fishes. Therefore, our findings suggest that $A$. paniculata was effective against $A$. hydrophila infection in aquaculture, thereby maintaining a healthy status of these fishes in aquaculture.
\end{abstract}

Keywords Skin ulcer $\cdot$ Mortality $\cdot$ Haematology $\cdot$ Histology $\cdot$ Survival

\section{Introduction}

Fish, an aquaculture food product stands a very valuable source of animal protein besides essential nutrients. Over the former times, aquaculture has stayed one among the fastest food-generating areas in the world (Bilen et al. 2016a; FAO

Responsible editor: Philippe Garrigues

Sengottayan Senthil-Nathan

senthil@msuniv.ac.in; senthilkalaidr@hotmail.com

1 Sri Paramakalyani Centre for Excellence in Environmental Sciences, Manonmaniam Sundaranar University, Alwarkurichi,

Tirunelveli, Tamil Nadu 627 412, India
2016). Aquaculture product including fish constitutes $20 \%$ of food consumption in developing countries (Béné et al. 2007). Fish contributes to near $50 \%$ of protein and minerals in the diet to the people of South Africa and Africa (Richardson et al. 2011). Due to the increasing demand of fish supply, aquaculture of economically important fishes is being established globally. However, cultivated fish are vulnerable to many diseases and an upsurge of disease epidemics has been reported owing to the escalation, resulting in above partial or full loss of production. Fish production from aquaculture is hindered by several limiting factors, for instance overcrowding, meagre water value, poor nutritional status and handling subsidize to physiological variations in fish such as trauma or immunosuppression and, therefore, amplify vulnerability to infection (Bilen et al. 2016b). Moreover, high concentrations of fish 
besides the deficiency of hygienic barriers ease the propagation of pathogens, creating high mortality varieties (Naylor et al. 2000; Cabello 2006; Quesada et al. 2013). Primary and opportunistic pathogens that propagate as a consequence of environmental stress are the common causes of diseases prevailing in aquaculture units in Asia (Lategan and Gibson 2003; Fang et al. 2004).

Aeromonas hydrophila is an opportunistic pathogen and is relatively more abundant in aquatic zones with a high organic load than in unpolluted water (Vasantha-Srinivasan et al. 2019a, 2019b). The Indian major carps (IMC) contribute between 70 and $75 \%$ of the entire freshwater fish production (Nandeesha et al. 2013; Edwin et al. 2016a, 2016b). Rohu (Labeo rohita), is a fresh water IMC that is widely cultivated in India. This species is survives easily and are cultured in a limited area, having a high demand besides being considered to be highly economical (FAO, STAT 2012; Nandeesha et al. 2013). However, this fish species is susceptible to A. hydrophila infection which causes severe damage, leading to $80-100 \%$ of the death rate within a week (Shankar et al. 2000).

The aquaculture farmers apply various antibiotics like ampicillin, tetracycline and chloroampiphinicol (Harikrishnan et al. 2011; Kamaraj et al. 2018), to control the A. hydrophila bacterial disease. But this bacterium is a heterogeneous species, having various antigens, so that vaccine development is extremely complex (Yin et al. 2009). The constant practice of using antibiotics can lead to the advance of antibiotic-resistant pathogens; the presence of these chemicals, left as residues in the fish, is dangerous for human consumption also causing harmful bioaccumulation impacts (Hidayat et al. 2018). Recently, herbal immunostimulants such as organic compounds from plants have been commonly used as an antibacterial and immunostimulant to control fish diseases (Cuesta et al. 2004; Ratnawati et al. 2013; Karina et al. 2015; Hardi et al. 2016a; Karina et al. 2016).

Increased interest in the stimulation of the fish non-specific immune system against pathogens, using botanicals, is developing (Alambra et al. 2012; Elkamel and Mosaad 2012; Harikrishnan et al. 2011; Menanteau-Ledouble et al. 2015; Misra et al. 2006; Satyantini et al. 2014; Zokaeifar et al. 2012) Non-specific defence mechanisms play a vital role in fish disease management throughout their life cycle. Fishes are comparatively more dependent on non-specific immune reactions for combating harmful pathogens than mammals (Harikrishnan and Balasundaram 2005). Herbal immunostimulants such as tetra Cotinus coggyria powder and extract (Bilen et al. 2011; Bilen et al. 2013; Bilen et al. 2014; Senthil-Nathan et al. 2005), Capperis spinose extract (Bilen et al. 2016a), Lactuca extract (Harikrishnan et al. 2011) and Urtica dioica extract (Bilen et al. 2016b) have been found effective against important fish pathogens. The dietary supplementation of $P$. guajava leaf extract significantly reduced the mortality and increased the disease resistance of Oreochromis mossambicus against $A$. hydrophila infection (Gobi et al. 2016). Several studies report the immunomodulatory effect of Bosenbergia Pandruta, Solanum ferox and Zingiber Zumbet methanol extracts by suppressing the growth of $A$. hydrophila, thereby enhancing disease resistance abilities (Hardi et al. 2016a, 2016b).

Andrographis paniculata is otherwise called Kalmegh (King of Bitters; Family Acanthaceae), native to Sri Lanka and India. Andrographolide $\left(\mathrm{C}_{20} \mathrm{H}_{30} \mathrm{O}_{5}\right.$, melting point 230 $239^{\circ} \mathrm{C}$ ) is a medicinal compound which is present in the foliage and root of the A. paniculata plant. The compound can be easily isolated from A. paniculata foliage as a crude extract (Rajani et al. 2000; Edwin et al. 2016a, 2016b). Andrographolide possess a multi-hepatoprotective property (Xu et al. 2006; Lin et al. 2009; Zhang et al. 2009; Wang et al. 2010; Chao et al. 2010; Jutti Levita et al. 2010; Tan et al. 2010; Zhou et al. 2010). Lately, the stimulation of immune function with the help of some medicinal plants (ecofriendly) in the aquaculture industry is gaining attention (Karthi et al. 2018; Chellappandian et al. 2018; Vivekanandhan et al. 2018a; Senthil-Nathan 2015; Vasantha-Srinivasan et al. 2019a, 2019b). This present study was performed to investigate the immune modulatory effect of A. paniculata on the non-specific immune parameters and its resistance to A. hydrophila pathogen in Labeo rohita.

\section{Materials and method}

\section{Fish sample collection}

Fingerlings of $L$. rohita, weighed $15.5 \pm 2.6 \mathrm{~g}$ (mean $\pm \mathrm{SD}$ ) were collected from a freshwater fish breeding centre (Govt Fish Seed Farm, Manimuthar Dam, Manimuthar, Tirunelveli District, Tamil Nadu (08 $36^{\circ} 40.3^{\prime \prime} \mathrm{N} 75^{\circ} 23^{\prime} 20.7^{\prime \prime}$ E) (Fig. 1). Sample fishes were secured and transported in oxygen-filled sterile plastic bags. Prior to the challenge test, the fishes were acclimatized to be grown under lab conditions for 7 days. The fishes are fed with commercial feed pellets two times a day ( $3 \%$ body weight).

\section{Collection of plant materials}

Aerial parts of healthy A. paniculata plants were collected during morning hours in Southern Western Ghats (Kallar site, (altitude 'M'-140 latitude $08^{\circ} 48^{\prime}$ 09.0" N). The collected plant material was identified by taxonomists from the Department of Plant Conservation and Biotechnology, Sri Paramakalyani Centre for Excellence in Environmental Sciences, Manonmanium Sundaranar University, Alwarkurichi, Tirunelveli, and the voucher specimen no. 1040 was submitted to the herbarium (Fig. 2). The samples 


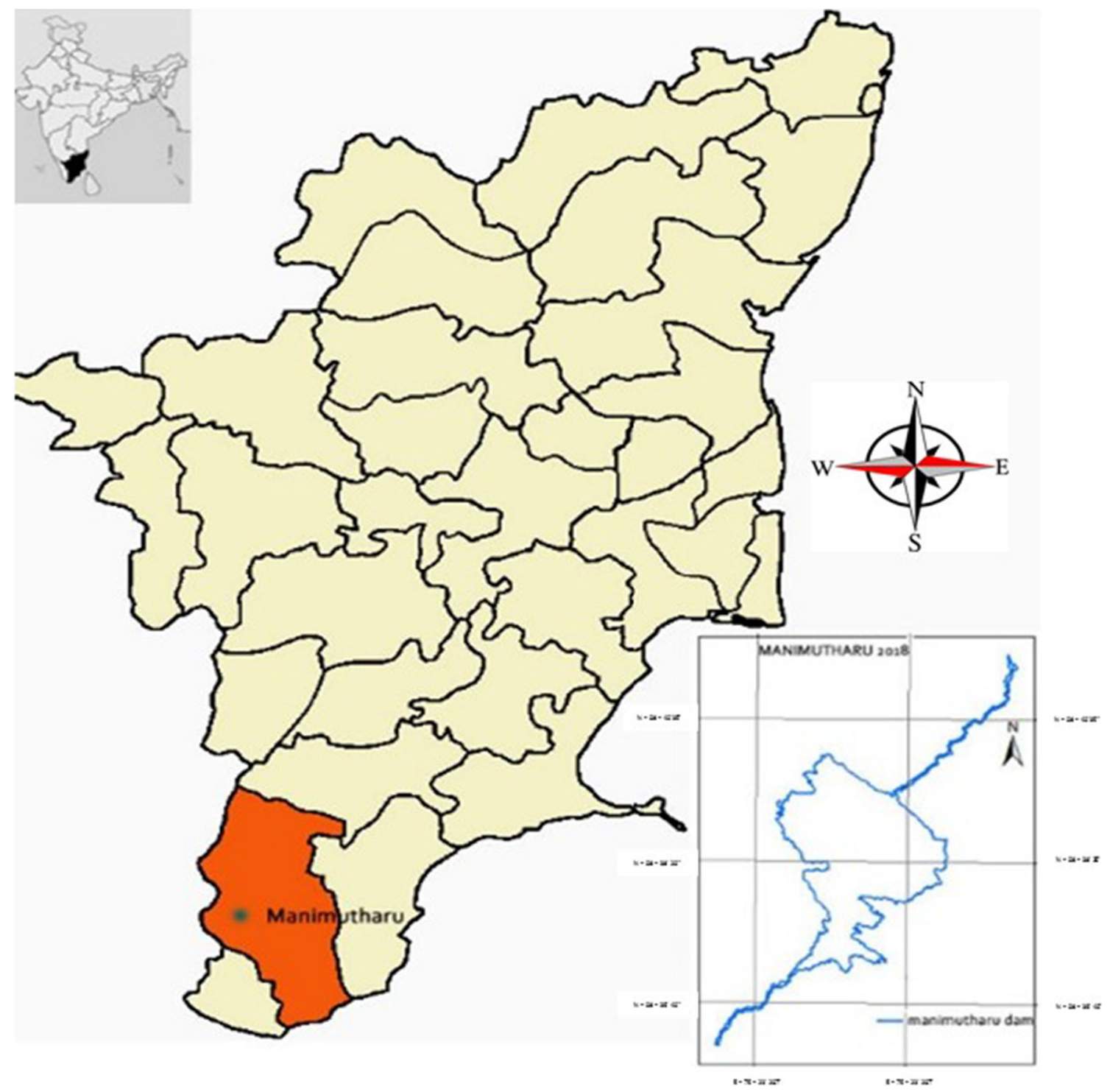

Fig. 1 Collection site of fish fingerling

were poised and washed initially with tap water and then with sterile water.

\section{Preparation of $A$. paniculata crude extract}

The collected plants were shade dried for 14 days at room temperature $\left(27-32^{\circ} \mathrm{C}\right)$ until they became brittle, then pulverized to powder in order to prevent photolysis and thermal degradation. Crude extracts were obtained by following standard extraction procedures (Harikrishnan and Balasundaram 2005; Hardi et al. 2014, 2016a). Dried plants were severed into minor fragments and ground to a coarse powder in an electrical stainless steel blender (Kumar et al. 2014). The powdered material $(100 \mathrm{~g})$ was subjected to Soxhlet extraction with methanol $(500 \mathrm{ml})$ for $48 \mathrm{~h}, 45-80{ }^{\circ} \mathrm{C}$ (Umamaheswari and Prince 2007. The residue was concentrated using a rotary vacuum evaporator to produce the crude extract (SenthilNathan 2007) and stored at $4{ }^{\circ} \mathrm{C}$. The crude extract was dissolved in $1 \%$ DMSO to facilitate complete solubilization in fish-containing tank water in diffusion method.

\section{Bacterial sample collection}

Aeromonas hydrophila culture was purchased from MTCC (MTCC-1739).

\section{Bacterial inoculum preparation for disease}

The bacterial culture was grown on nutrient agar plates and was used for pathological experiments. Serially diluted 24-h old culture $\left(10^{8} \mathrm{CFU} / \mathrm{ml}\right)$ was centrifuged at $3000 \mathrm{~g} / 10 \mathrm{~min}$. The pellet was washed with phosphate buffer saline (PBS) and 
Fig. 2 Morphology of Andrographis paniculata
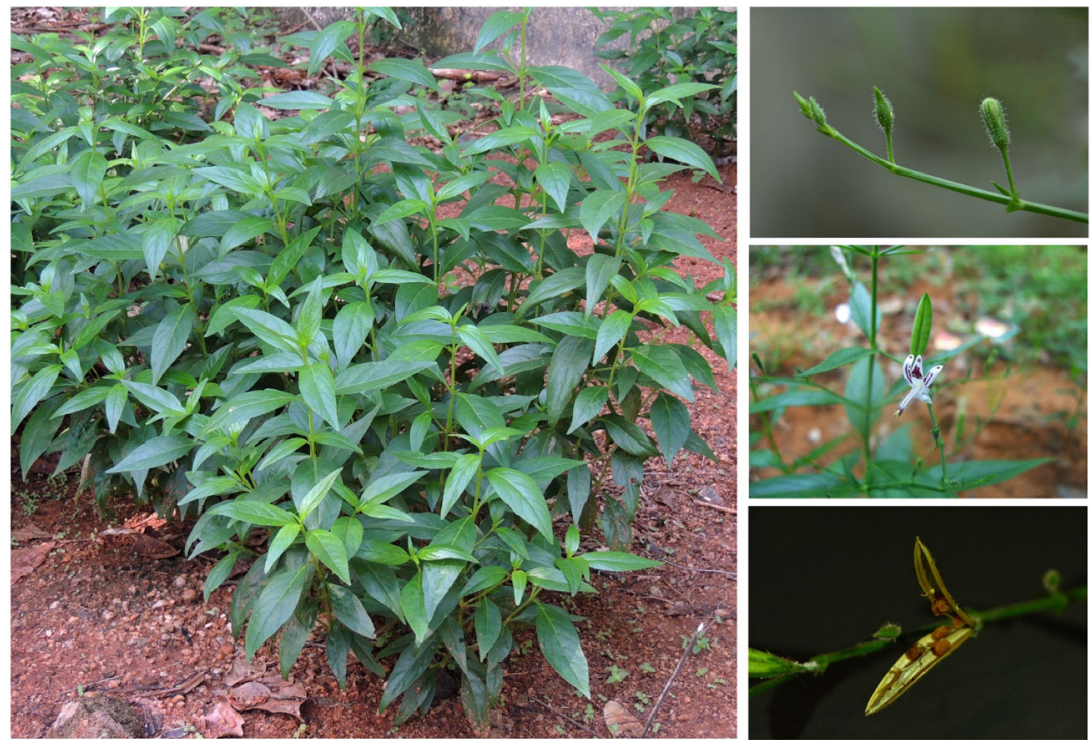

the $\mathrm{LD}_{50}$ density of the bacteria was adjusted up to $10^{8} \mathrm{CFU} /$ $\mathrm{ml}$ to be used for bioassays (Ben-David and Davidson 2014; Chelladurai et al. 2017; Hardi et al. 2014).

\section{Antimicrobial assay}

Antibacterial assays were performed using crude extracts of different concentrations $(50,100,150$ and $200 \mu \mathrm{l})$ using the well diffusion method. The broth dilution method was used to estimate the minimum inhibitory concentration (MIC) (Devillers et al. 1989; Hardi et al. 2016c).

\section{Design of experimental challenge test}

This analysis was done by using different experimental treatments, (Table 1). After a 2-day acclimatization period, the fishes were further conditioned for challenge tests. The fingerlings were transferred to tanks containing clean water for 1 week $\left(27 \pm 1{ }^{\circ} \mathrm{C}, \mathrm{pH} 7.2 \pm 0.4\right.$, Salinity $10 \pm 3$ and DO $>6.5 \mathrm{mg}^{-1}$ ). The feed was changed from commercial feed pellets to rice bran and groundnut oil cake. The bioassays were carried out by administrating $0.1 \mathrm{ml}$ of extract to the fishes via intraperitoneal injection, oral feeding and diffusion methods (Table 1). All treatments were repeated thrice.

In the injection method, $0.1 \mathrm{ml}$ of the extract was administered by intraperitoneal injection. In the oral feeding method, the extract $(0.1 \mathrm{ml})$ was administrated to the fish by supplementing with feed (Hardi et al. 2017); In the diffusion method, the fish were allowed to swim in the water tanks added with $0.1 \mathrm{ml}$ of crude extract for $30 \mathrm{~min}$ (Cipriano et al. 1984; Hardi et al. 2017). The same day after treatments, the fish was challenged with $A$. hydrophila $\left(10^{8} \mathrm{CFU} / \mathrm{ml}^{-1}\right)$ inoculated via intramuscular injection. The treated fishes were observed for 28 days.

\section{Blood drawing and preparation}

Blood $(0.2 \mathrm{ml})$ was drawn from the fish caudal vein by means of a syringe containing a pinch of anticoagulant (EDTA). Blood parameters such as erythrocyte-leucocyte counts and haemoglobin level were analysed by drawing blood on days 0, 7, 14 and 28 (pre-injection, injection time and post-injection time, respectively).

\section{Total erythrocyte count}

Total erythrocyte count (TEC) was done by drawing blood (0.5-scale pipette) and using Hayman solution (till scale 101). The combination was mixed well by shaking with a motion resembling the form of number 8 . The cells were counted in a haemocytometer viewed under a fluorescent microscope ( $\times$ 40; Optika, Japan; Blaxhall and Daisley 1973).

Table 1 Treatments profile of the Rohu (Labeo rohita) fish

\begin{tabular}{llll}
\hline S. no. & Treatments & A. hydrophila $\left(10^{8} \mathrm{CFU} / \mathrm{ml}^{-1}\right)$ & $\begin{array}{l}\text { A. paniculata } \\
\text { Extract }\end{array}$ \\
\hline 1 & (i) Control & - & - \\
2 & (ii) & $0.1 \mathrm{ml}$ & $50 \mu \mathrm{l}$ \\
3 & (iii) & $0.1 \mathrm{ml}$ & $50 \mu \mathrm{l}$ \\
4 & (iv) & $0.1 \mathrm{ml}$ & $100 \mu \mathrm{l}$ \\
5 & (v) & $0.1 \mathrm{ml}$ & $200 \mu \mathrm{l}$ \\
6 & (vi) & $0.1 \mathrm{ml}$ & PBS $50 \mu \mathrm{l}$ \\
\hline
\end{tabular}

$P B S$, phosphate buffer saline 


\section{Haemoglobin test}

The haemoglobin level was tested using a salinometer (Wedemeyer and Yasutake 1977). Distilled water was used to dilute the drawn fish blood colour to resemble the standard colour in the salinometer. The haemoglobin concentration was cited as $\mathrm{g} \%$.

\section{Total leukocyte count}

Total leucocyte was counted by drawing the blood sample on a 0.5-scale pipette (Anderson and Siwicki 1995a). The first droplet was added to the haemocytometer and covered with a coverslip. The cells were counted by viewing the haemocytometer under a fluorescent microscope $(\times 40$; Optika, Japan).

\section{Phagocytic index analysis}

The effect of A. hydrophila on fish blood was observed by analysing the phagocytic index. Fish blood was mixed with A. hydrophila suspension $\left(10^{5}\right.$ cells $\left./ \mathrm{ml}\right)$ and extracts $(50 \mathrm{ppm})$ and incubated at room temperature for $20 \mathrm{~min}$. The suspension was carried forward for estimating the phagocytosis index (PI) by placing few drops on a slide and observed under a microscope ( $\times 40$; Optika, Japan). The number of cells showing phagocytosis was counted and expressed PI was as $\%$ (Anderson and Siwicki et al. 1995b).

\section{Resistance to bacteria}

The fishes were observed for changes in swimming patterns and anatomy post bacterial infection as well as after treatments with A. panniculata extracts on both live and dead fishes on the 14th day. The symptomatic change coding was categorized into four levels and rated on a scale (Table 2).

Fish injected with $A$. hydrophila was monitored for mortality every day (0 to 28). A. hydrophila was re-isolated from the liver and kidney of the dead fish, cultured in Rimler-Shotts agar medium to confirm the pathogenicity of A. hydrophila. Additionally, the relative percentage of survival (RPS) study was calculated by using the Ellis (1988) formula.

Table 2 Calculation of infection index for Rohu

\begin{tabular}{llll}
\hline S. No & Infection index & Percentage & Indicator \\
\hline 1 & Normal & 0 & $\wp$ \\
2 & Low & $<20$ & $\checkmark$ \\
3 & Medium & $<20-50$ & $\checkmark \checkmark$ \\
4 & High & $<50$ & $\checkmark \checkmark \checkmark$ \\
\hline
\end{tabular}

RPS $=1-\frac{(\text { Percent mortality in treated group })}{\text { Percent mortality in control group }} \times 100$

\section{Histology}

The gill and liver of infected fish were isolated for histological studies (Roberts and Rodger 2012). Gill and liver samples $\left(1 \mathrm{~cm}^{3}\right)$ were taken aseptically from the infected fish and were fixed with $10 \%$ buffered formalin. Then, the samples were subjected to trimming and processed in an automatic tissue processor for dehydration, clearing, and infiltration for $21 \mathrm{~h}$. The samples were sectioned and stained with haematoxylin and eosin (Nahar et al. 2016). They were then allowed to dry overnight and the cell structures were observed by using a light microscope (Nikon, Eclipse, E 800).

\section{Statistical analysis}

The experimental data were analysed using ANOVA. Differences between the treatments were determined by Tukey's test $(P=0.05)$ (Snedecor and William 1989).

\section{Results}

\section{Minimum inhibitory concentration}

The methanolic extracts of Andrographis paniculata exhibited antibacterial activity against $A$. hydrophila, with an MIC of $50 \mu \mathrm{l}$, in a 2-h time duration (Table 3).

\section{TEC and Heamoglobin levels}

The application of A. paniculata extracts $(50 \mathrm{mg} / 1,100 \mathrm{mg} / \mathrm{l}$, $150 \mathrm{mg} / \mathrm{l}$ and $200 \mathrm{mg} / \mathrm{l}$ ) enhanced the total erythrocyte count and the normal haemoglobin levels in the injection (Table 4), oral feeding (Table 5) and diffusion methods (Table 6).

The fish infected with $A$. hydrophila displayed $\mathrm{Hb}$ and TEC levels significantly lower than those of the control, 4$5 \mathrm{~g} \%$ and 22-23 cells $\mathrm{mm}^{-3}$ respectively (Table 4,5 , and 6). The fish treated with plant extracts increased the haemoglobin and TEC levels from $9-9.5 \mathrm{~g} \%$ to $9-13 \mathrm{~g} \%$ and $29-30.8$ to $32-37.7 \times 10^{5}$ cells $\mathrm{mm}^{-3}$,respectively, in all the treatment methods $(P<0.005)$. Among the three treatment methods, there was a significant rise in $\mathrm{Hb}(13 \mathrm{~g} \%)$ and TEC levels $\left(37.7 \times 10^{5}\right.$ cells $\left.\mathrm{mm}^{-3}\right)$.

\section{Total leucocyte}

Total leucocyte count (TLC) of the fish supplemented with different dosages of A.paniculata extracts increased and differed significantly, compared with that of the control on the 
Table 3 MIC of the methanol extract of herbal plants against A. hydrophila

A. hydrophila + different concentrations of extract $(\mu \mathrm{g} / \mathrm{ml})$

\begin{tabular}{lllllll}
\cline { 2 - 6 } Plant extracts & 0 & 10 & 25 & 50 & 100 & 200 \\
\hline Andrographis paniculata & + & + & + & - & - & - \\
\hline
\end{tabular}

'0' control, ('+' growth), ('- no growth)

28th day $(P<0.0005)$. A. hydrophila infection reduced the TLC levels (Fig. 3). The plant extracts increased the TLC levels of A. hydrophila-infected fishes from 2.6-3.0 to 3.2$4.9 \times 10^{5}$ cells $\mathrm{mm}^{-3}$.

This result indicated that A.paniculata extracts were able to increase the production of leucocyte significantly as a defence mechanism against pathogenic bacteria infection at the end of the treatment. The TLC levels increased with treatments in a dose-dependent manner. However, at higher concentrations, 150 and $200 \mu \mathrm{l}$, the TLC levels did not differ significantly $(P>0.005)$. TLC values of treated infected fishes were significantly higher in the injection method, which did not differ significantly with that of the oral feeding method $\left(4.9 \times 10^{5}\right.$ cells $\left.\mathrm{mm}^{-3}\right)(P>0.005)$.

\section{Phagocytosis index}

Phagocytosis index of Rohu fishes treated with plant extracts increased in a dose-dependent manner at a day 14 and day 28 . On days 0,7 and 14, no significant difference in PI values of treated and untreated fishes was observed. However, the PI values on day 28 increased and differed significantly with that of control fishes $(P<0.005)$. The A. paniculata treatment by the injection method increased the PI of fishes reaching $61.40 \%$ from $20.30-21.30 \%$ (Fig. 4) after 14 days. The extracts also increased the PI of infected fishes to 47.40 and $61.40 \%$ at respective 100 and $200 \mu \mathrm{l}$ treatment concentrations $(P<0.005)$. However, the PI increase at dosage treatments 150 and $200 \mu \mathrm{l}$ was not significantly different $(P>0.005)$.

\section{Anatomy and physiological changes}

Fishes infected with the A. hydrophila pathogen displayed changes in its external and internal organs such as fin rot, skin ulcer, damage in gill, loss of scale, haemorrhagic septicaemia (Fig. 5b). The treatment of infected fishes with A. paniculata started to disappear gradually from day 14 and completely vanished on day 28 . Among the treatment methods, oral feeding was very effective followed by diffusion and injection methods (Tables 7 and 8).

\section{Histology analysis of gill}

Histopathological changes were observed in the gill of the infected Rohu fishes. The infected fishes exhibited haemorrhages at the base of the fins, erosion of the pectoral fins, ulcers on the skin surfaces and fin rot after $72 \mathrm{~h}$ of infection. Normally, the surface of the gill lamellae (GF) was covered with epithelial cells running in a parallel position (Fig. 6a). Primary lamellae (PL), secondary lamellae (SL), nucleated erythrocyte ( $\mathrm{Er}$ - black arrow), gill of the infected fishes after $24 \mathrm{~h}$ completely collapsed with GF lamellar aneurysm (L), damaged primary lamellae (DPL) and damaged secondary lamellae (DSL) (Fig. 6b). Completely detached filament degraded secondary lamellae (shown as a yellow arrow) and clusters of bacterial cells (BC) in the filament were also observed.

\section{Histology analysis of liver}

The liver is the largest extramural organ that contains heatopoietic tissue and macrophage aggregates. Overall, the control group showed normal hepatocytes $(\mathrm{NH})$, blood vessels (BV) and blood sinusoids (BS) (Fig. 6a). Blood sinusoids were lined with reticulo-endothelial cells, which were surrounded by hepatocytes. After infection with A. hydrophila, the hepatocyte cells were completely damaged and an influx of blood cells in capillaries occurred (Fig. 6b).

Table 4 Blood profile of the Rohu (Labeo rohita) fish treated with extracts for prevention of A. hydrophila from 0 to 14 and 28 days

\begin{tabular}{|c|c|c|c|c|c|c|}
\hline \multirow[t]{2}{*}{ Treatments } & \multicolumn{3}{|c|}{ Haemoglobin $(\mathrm{g} \%)$} & \multicolumn{3}{|c|}{ Total erythrocyte $\left(10^{5}\right.$ cells $\left.\mathrm{mm}^{-3}\right)$} \\
\hline & D0 & D14 & D28 & D0 & D14 & D28 \\
\hline No extract, no pathogen & 9 & 9 & 9.5 & 29.7 & 30 & 30.8 \\
\hline A. paniculata $50 \mu \mathrm{l}$, A. hydrophila & 9 & 10.2 & 11.5 & 27 & 31.5 & 32 \\
\hline A. paniculata $100 \mu \mathrm{l}$, A. hydrophila & 10 & 11 & 12 & 21 & 31 & 33 \\
\hline A. paniculata $150 \mu \mathrm{l}$, A. hydrophila & 9 & 11 & 12.5 & 25 & 32.3 & 34.7 \\
\hline A. paniculata $200 \mu \mathrm{l}$, A. hydrophila & 10 & 11.5 & 13 & 29 & 32.2 & 37.7 \\
\hline No extract only A. hydrophila & 9 & 6 & 4 & 28.1 & 24 & 23 \\
\hline
\end{tabular}

D0, day $0 ; D 14$, day $14 ; D 28$, day 28 
Table 5 Blood profile of the Rohu (Labeo rohita) fish treated with extracts for prevention of A. hydrophila from 0 to 14 and 28 days

\begin{tabular}{|c|c|c|c|c|c|c|}
\hline \multirow[t]{2}{*}{ Treatments } & \multicolumn{3}{|c|}{ Haemoglobin $(\mathrm{g} \%)$} & \multicolumn{3}{|c|}{ Total erythrocyte $\left(10^{5}\right.$ cells $\left.\mathrm{mm}^{-3}\right)$} \\
\hline & D0 & D14 & $\mathrm{D} 28$ & D0 & D14 & D28 \\
\hline No extract, no pathogen & 9 & 9 & 9.5 & 29.7 & 30 & 30.8 \\
\hline A. paniculata $50 \mu 1$, A. hydrophila & 10 & 10.2 & 11.5 & 27.5 & 31.5 & 32 \\
\hline A. paniculata $100 \mu \mathrm{l}$, A. hydrophila & 9 & 10.5 & 12 & 21.7 & 31 & 33.0 \\
\hline A. paniculata $150 \mu \mathrm{l}$, A. hydrophila & 9 & 11 & 12.5 & 25.4 & 32 & 34.5 \\
\hline A. paniculata $200 \mu \mathrm{l}$, A. hydrophila & 10 & 11.5 & 13 & 29 & 32.2 & 37.1 \\
\hline No extract only A. hydrophila & 9 & 7 & 5 & 28.1 & 24 & 23 \\
\hline
\end{tabular}

D0, day $0 ; D 14$, day $14 ; D 28$, day 28

Blood congestion in the sinusoids and hypertrophy $(\mathrm{H})$ of hepatocytes were observed.

\section{Changes in swimming pattern}

A. hydrophila-infected fishes displayed changes in swimming patterns and behaviours that were evident by visual observations. The fishes exhibited unstable swimming patterns by swimming up to the surface water, gasping and settling down in the fish tank. They also displayed signs of weakness and aggressive behaviour when touched.

However, after treatment, the fish exhibited ordinary behaviour. Interestingly, gasping and aggressive response were not observed in fish treated with the extracts and only a few of the fish displayed debilitated swimming behaviour and stayed at the bottom of the aquarium (Table 9).

\section{Cumulative mortality and death rate}

The fishes infected with $A$. hydrophila displayed higher cumulative mortality rate $(\mathrm{CMR})$ and cumulative death rate (CDR) that were significantly different from control and treatment rates (Figs. 7 and 8). The fishes treated with the extracts of A. paniculata displayed CMR less than $30 \%$ (Fig. 7). The CMR was lower in fishes treated with lower doses of extracts.
The CDR of fishes infected with A. hydrophila was significantly higher compared with that of the control and treated fishes $(P<0.005)$. Moreover, the CDR of infected fishes treated with $50 \mu \mathrm{l}$ A. paniculata extracts in all the treatment methods and control were not significantly different, implying the safety and efficacy of the extracts in fishes against A. hydrophila infection (Fig. 9).

\section{Relative percentage survival}

Fishes treated with a lower dose of $50 \mu \mathrm{l}$ A. paniculata extract displayed RPS rates that were significantly higher than those of the control $(P<0.005)$ (Fig. 9). However, at higher treatment dosages, the infected fishes exhibited lower RPS rates compared with those of the control implicating the toxicity of extracts at concentrations higher than $50 \mu \mathrm{l}$ in all the three treatment concentrations.

\section{Discussion}

As an important sector of the food industry, aquaculture is a rapidly developing trade in terms of production and revenue. In order to meet high demands, fish farmers are intensifying fish cultures globally. This has resulted in several ill effects such as overstressing as well as disease outbreaks leading to

Table 6 Blood profile of the Rohu (Labeo rohita) fish treated with extracts for prevention of A. hydrophila from 0 to 14 and 28 days

\begin{tabular}{|c|c|c|c|c|c|c|}
\hline \multirow[t]{2}{*}{ Treatments } & \multicolumn{3}{|c|}{ Haemoglobin $(\mathrm{g} \%)$} & \multicolumn{3}{|c|}{ Total erythrocyte $\left(10^{5}\right.$ cells $\left.\mathrm{mm}^{-3}\right)$} \\
\hline & D0 & D14 & D28 & D0 & D14 & D28 \\
\hline No extract, no pathogen & 9 & 9 & 9.5 & 29 & 30 & 30.8 \\
\hline A. paniculata $50 \mu \mathrm{l}$, A. hydrophila & 10 & 10.2 & 11 & 27 & 31 & 32 \\
\hline A. paniculata $100 \mu \mathrm{l}$, A. hydrophila & 9 & 11 & 11 & 21.8 & 31.8 & 33 \\
\hline A. paniculata $150 \mu \mathrm{l}$, A. hydrophila & 9 & 11 & 12 & 25.6 & 32.5 & 34.5 \\
\hline A. paniculata $200 \mu \mathrm{l}$, A. hydrophila & 10 & 11.5 & 12.5 & 29 & 33.6 & 36 \\
\hline No extract only $A$. hydrophila & 10 & 7 & 5 & 28.5 & 26 & 22 \\
\hline
\end{tabular}

$D 0$, day $0 ; D 14$, day $14 ; D 28$, day 28 
Fig. 3 Total leucocyte count (TLC) of Rohu in the injection, oral feeding and diffusion methods. a A. paniculata $50 \mu \mathrm{l}$, A. hydrophila. b A. paniculata $100 \mu \mathrm{l}$, A. hydrophila. c A. paniculata $150 \mu \mathrm{l}$, A. hydrophila. $\mathbf{d}$ A. paniculata $200 \mu \mathrm{l}$, A. hydrophila

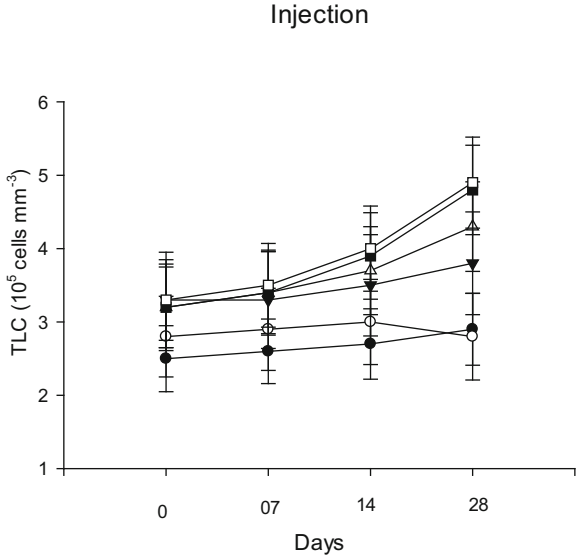

Oral feeding

Diffusion
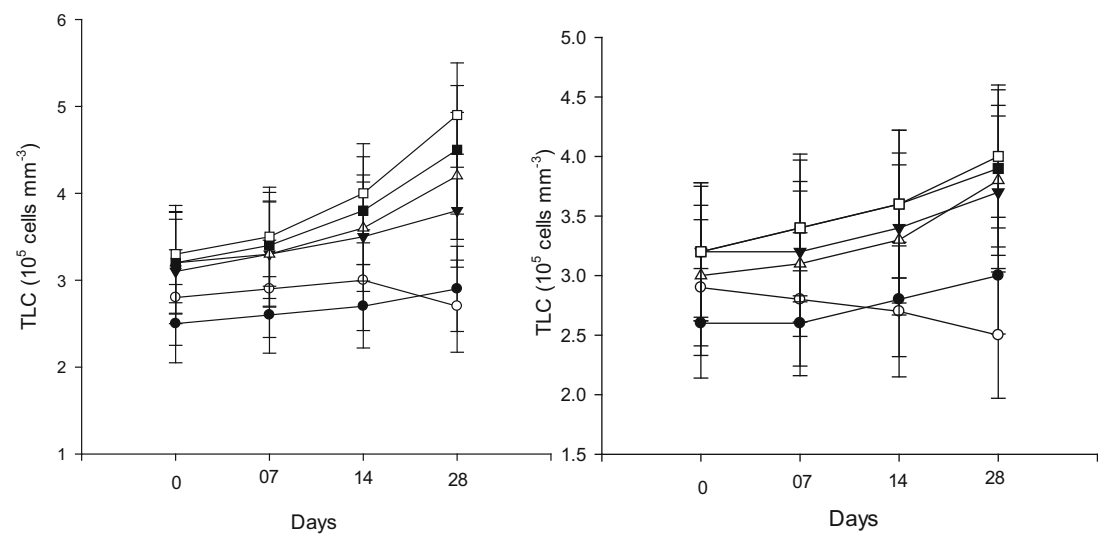

$\longrightarrow$ - A. hydrophila

A. paniculata $50 \mu \mathrm{l}+A$. hydrophila A. paniculata $100 \mu l+A$. hydrophila - A. paniculata $150 \mu l+A$. hydrophila $\square-$ A. paniculata $200 \mu \mathrm{l}+A$. hydrophila<smiles>[I-]</smiles>

severe yield loss. Besides the careless and overuse of chemicals for disease management, alternative disease control methods to stimulate fish non-specific immune response to confer disease resistance are being emphasized by ichthyologists worldwide. The usages of natural immunostimulants that are eco-friendly, biodegradable and safe are being preferred for aquaculture disease management lately (Raa et al. 1992; Ortuno et al. 2002; Palanikani et al. 2018).

Amidst the vital fish species cultured in India, Indian carps Catla (Catla catla), Rohu (Labeo rohita), and Mrigal (Cirrhinus mrigala) are of high commercial value (FAO 2016). Disease has caused mass mortalities to the Indian aquaculture industry, with a special regard to motile Aeromonas infections (Paniagua et al. 1990; Alain 2009; Govind et al. 2012). The non-specific immune system of Rohu fishes consists of cellular and humoral components. Cellular components include monocytes, lympocytes, neutrophiles and macrophages, while the humoral components include lysozymes and complements (Magnadóttir 2006). Phagocytosis in fish plays a pivotal role in eliminating disease-causing pathogens. Plant extracts as immunostimulants are regarded as the good alternatives for synthetic chemicals. In addition, some probiotics are also used to manage bacterial diseases, yet the probiotics only suppress the growth of pathogenic bacteria rather than eradicating the pathogen (Hardi et al. 2016c; Ponsankar et al. 2019).

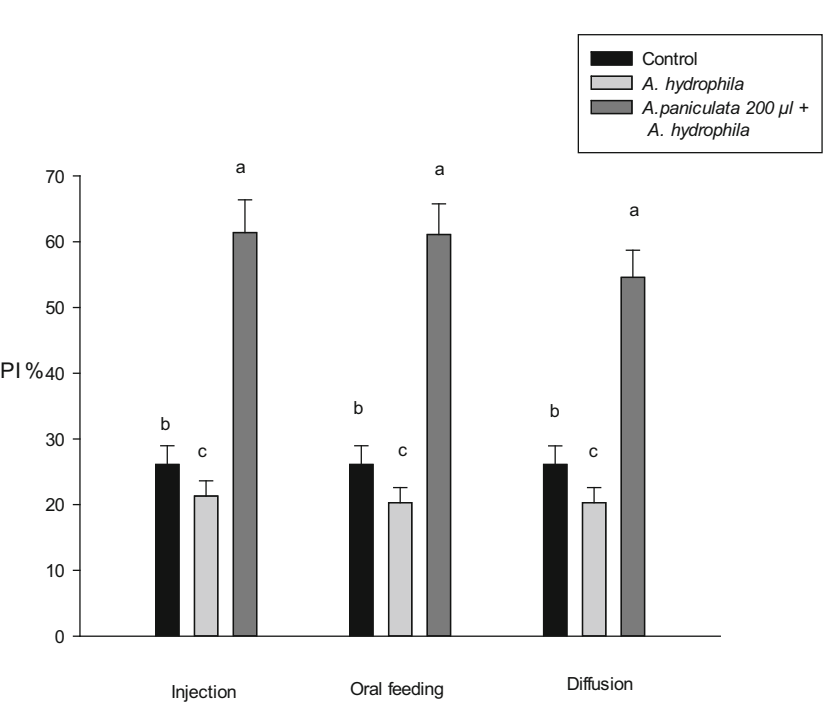

Fig. 4 Phagocytosis index of Rohu in the injection, oral feeding and diffusion methods 
Fig. 5 a Control (IMC) Labeo rohita. b Infected (IMC) Labeo rohita. SU, skin ulcer; LS, loss of scale; HS, haemorrhagic septicaemia; FN, fin rot
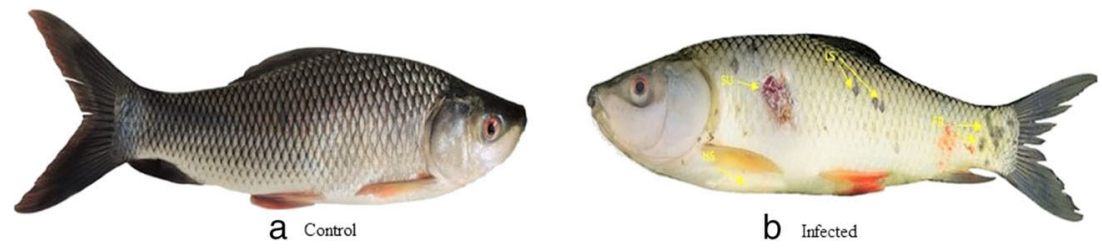

With vaccines only targeting a specific type of bacteria (Hardi et al. 2013) and the necessity of the application of a booster dose for controlling the fish infections leading to the development of resistance among the pathogens, plantbased disease management strategies were focussed Kesarcodi-Watson et al. 2008; Nugroho and Fotedar 2013). Some plant extracts are reported with immunostimulant and antibacterial activities that can provide effective disease control (Vivekanandhan et al. 2018a, 2018b; Venkatalakshmi and Michael 2001; Hardi et al. 2016a, 2016b) and some viral growth (Saptiani et al. 2016a, 2016b). Hence, the study was focused on controlling the Aeromonas infection through stimulating the nonspecific immune response of Rohu by the application of A. paniculata extracts.

The pathogenicity of A. hydrophila was determined by exposing the pathogen to Rohu fishes via the injection method. All the Rohu fishes developed rapid changes in their anatomy, physiology and swimming patterns post challenge with the pathogen. The disease symptoms intensified with time due to pathogen proliferation and additional entry into the fish facilitated by some injuries as Rohu fishes do not have protection scales and their sharp fins can easily tear the skin of another fish within the immediate vicinity. Similar symptoms on fish infected with A. hydrophila as well as Pseudomonas sp. were also observed (Cipriano et al. 1984; Afifi and Guerrero 2000 Al-Faragi and Alsaphar 2012; Mhaisen et al. 2013; Stratev et al. 2015; Kumar et al. 2016; Abdelhamed et al. 2017).

Rohu fishes infected with A. hydrophila displayed symptoms in varied levels of severity. Those treated with
A. paniculata extracts exhibited moderate symptoms. It was also reported that the severity of symptoms depends upon the immunological status of the fishes. The higher the immnumological efficiency, the lower the infection. Subsequently, the lower infection levels caused only medium levels of external symptoms. This was also reported by Sheeba (2012) and Hardi et al. (2017), who reported anatomical changes in Nile tsilapia challenged with A. hydrophila as well as Pseudomonas sp.

Fishes infected with pathogens exhibit clinical signs such as alterations in swimming patterns (El-Ghany and Alla 2008). Besides the external symptoms, the infected fishes also displayed changes in swimming patterns and behaviours such as gasping and weakness along with vigorous movements and settling at the bottom of the tank. The infected fishes also displayed haemorrhage at the base of the fins, erosion of the pectoral fins, skin ulcer of the surface and septicaemia. The appearance of these symptoms and anatomical-physiological changes confirms the pathogenicity of A. hydrophila by comparing with previously reported works of Yambot and Inglis (1994), who reported acute mortality among Nile tilapia caused by $A$. hydrophila.

Horne and Baxendale (1983) and Kanno et al. (1989) also reported the adherence of bacteria to the intestine, gill and skin. A. hydrophila is capable of damaging the host organs such as the gill, liver, intestine and heart. The histology of the gills and liver in infected Rohu showed similar patterns of deterioration. The gills of infected fish collapsed completely after $24 \mathrm{~h}$ of infection, exhibiting haemorrhages and erosion at the fin base and pectoral fins respectively and skin ulcer as well as fin rot after $72 \mathrm{~h}$. The lamellar aneurysm was damaged

Table 7 Anatomic, physiological and swimming patterns of Rohu after the challenge test treated with A. hydrophila in the injection method

\begin{tabular}{|c|c|c|c|c|c|c|}
\hline \multirow[t]{2}{*}{ Treatments } & \multicolumn{6}{|c|}{ Anatomic and wimming pattern changes } \\
\hline & Fin rot & Skin ulcer & Damage in gill & Loss of scale & Gasping & Weakness \\
\hline No extract no pathogen & o & o & o & o & o & o \\
\hline A. paniculata $50 \mu \mathrm{l}$, A. hydrophila & $\checkmark$ & $\checkmark \checkmark$ & $\checkmark$ & $\checkmark$ & $\checkmark$ & $\checkmark$ \\
\hline A. paniculata $100 \mu \mathrm{l}$, A. hydrophila & o & $\checkmark$ & $\checkmark$ & o & $\checkmark$ & $\checkmark$ \\
\hline A. paniculata $150 \mu \mathrm{l}$, A. hydrophila & o & $\circ$ & $\circ$ & o & $\circ$ & o \\
\hline A. paniculata $200 \mu \mathrm{l}$, A. hydrophila & 0 & $\circ$ & $\circ$ & o & 0 & o \\
\hline No extract only A. hydrophila & $\checkmark \checkmark$ & $\checkmark \checkmark$ & $\checkmark \checkmark$ & $\checkmark \checkmark$ & $\checkmark \checkmark$ & $\checkmark \checkmark \checkmark$ \\
\hline
\end{tabular}

$D 0$, day $0 ; D 14$, day $14 ; D 28$, day 28

Normal $(\circ)$, low $(\checkmark)$, medium $(\checkmark \checkmark)$, high $(\checkmark \checkmark \checkmark)$ 
Table 8 Anatomic, physiological and swimming pattern of Rohu after the challenge test treated with A. hydrophila in the oral feeding method

Treatments Anatomic and swimming pattern changes

\begin{tabular}{|c|c|c|c|c|c|c|}
\hline & & & & & & \\
\hline & Fin rot & Skin ulcer & Damage in gill & Loss of scale & Gasping & Weakness \\
\hline No extract, no pathogen & o & o & 0 & o & o & o \\
\hline A. paniculata $50 \mu 1$, A. hydrophila & $\checkmark$ & $\checkmark$ & $\checkmark$ & $\checkmark$ & $\checkmark$ & $\checkmark \checkmark$ \\
\hline A. paniculata $100 \mu \mathrm{l}$, A. hydrophila & o & $\checkmark$ & $\checkmark$ & $\checkmark$ & $\checkmark$ & $\checkmark$ \\
\hline A. paniculata $150 \mu \mathrm{l}$, A. hydrophila & o & O & o & o & o & o \\
\hline A. paniculata $200 \mu \mathrm{l}$, A. hydrophila & o & o & o & o & o & o \\
\hline No extract only A. hydrophila & $\checkmark \checkmark$ & $\checkmark \checkmark$ & $\checkmark \checkmark$ & $\checkmark \checkmark$ & $\checkmark \checkmark$ & $\checkmark \checkmark \checkmark$ \\
\hline
\end{tabular}

Normal (o), low $(\checkmark)$, medium $(\checkmark \checkmark)$, high $(\checkmark \checkmark \checkmark)$

and the secondary lamellae degraded by detached filament, showing clusters of bacterial cells. After infection with A. hydrophila, the hepatocyte cells were completely damaged and the presence of blood cells that have influxed from the capillaries was reported. Additionally, blood congestion in the sinusoids and hypertrophy of hepatocytes were also observed. Similar histological observations were reported by several researchers as a result of $A$. hydrophila in several fish species (Khamees et al. 2013; Stratev et al. 2015; Kumar et al. 2016; Abdelhamed et al. 2017). Based on these observations, the pathogenicity of A. hydrophila was confirmed.

Management of A. hydrophila in an aquaculture system is extremely difficult and the development of resistance against chemical control methods is further complicating the disease control programs (Wang and Weller 2006). Several plants were recorded with antibacterial activity against A. hydrophila (Cipriano 2001; Obi et al. 2007; Mahfuzul Hoque et al. 2007; Al Laham and Al Fadel 2014). Few of the plant bioactive compounds in clove (eugenol) and cinnamon (eugenol and cinnamaldehyde) have been reported with higher antagonistic activities against $A$. hydrophila (Ramena et al. 2018).

In the current research, the methanol extracts of A. paniculata were found to be very effective against A. hydrophila even at $50 \mu \mathrm{l}$ (MIC). The derivatives of A. paniculata such as isoandrographolide, neoandrographolide, andrographolide and isoandrographolide are reported to poses several bioactivities such as antimalarial, anti-diabetic, anti-viral, anti-inflammatory and immunostimulatory activities (Tajuddin and Tariq 1983; Yu

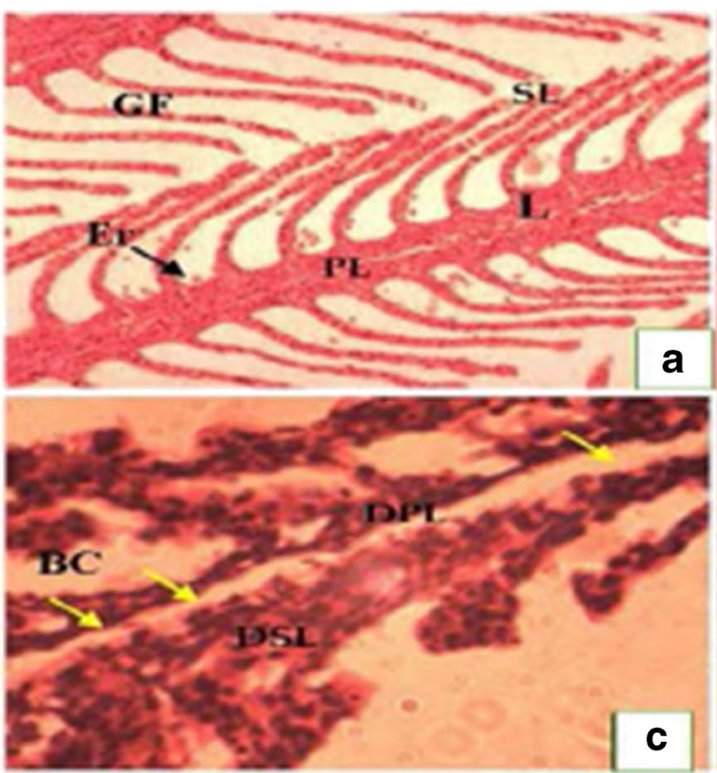

Fig. 6 a, b Histology analysis of the gill and liver. a Control group showing gill filament (GF), secondary lamellae (SL), nucleated erythrocyte (Er). Haematoxylin and eosin $\times 100$ (Labeo rohita). b The Gills of infected fish after $72 \mathrm{~h}$, completely collapsed GF, damaged primary lamellae (DPL), lamellar aneurysm (SL) and damaged secondary lamellae (DSL); clusters of bacterial cells (BC) in filament (yellow

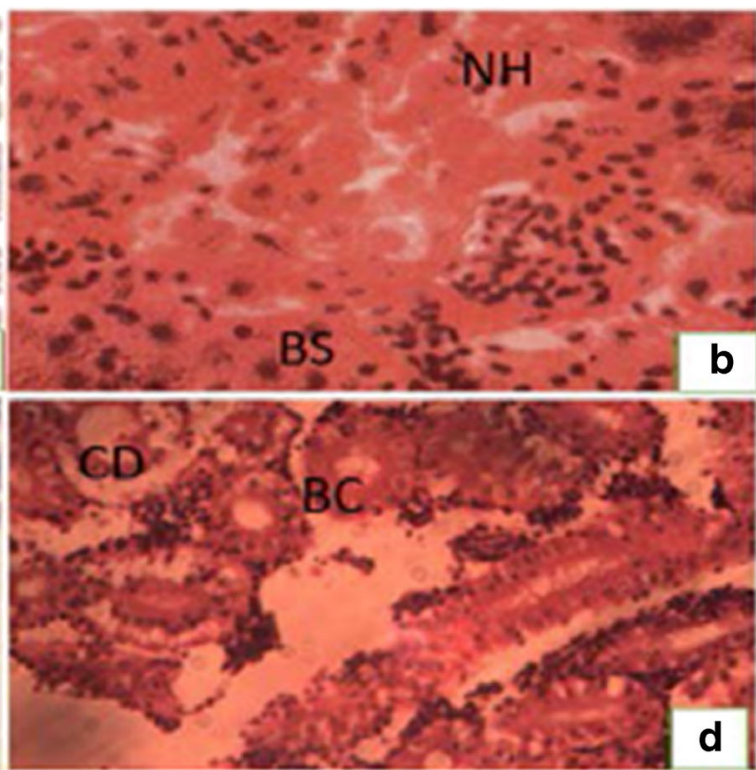

arrow), (Labeo rohita). Haematoxylin and eosin $\times 100$. c Control group showing normal hepatocyte (HC), blood vessels (BV) and blood sinusoids (BS). Haematoxylin and eosin $\times 100$ (Labeo rohita). d The liver infected with A.hydrophila; cells of hepatocytes are completely damaged with influx of blood cells (BC) in capilliaries and cytoplasmic degeneration $(\mathrm{CD})$. Haematoxylin and eosin $\times 100$ (Labeo rohita) 
Table 9 Rohu (Labeo rohita) — anatomic and physiological and swimming pattern changes occurred after the challenge test to A. hydrophila in the diffusion method

\begin{tabular}{|c|c|c|c|c|c|c|}
\hline \multirow[t]{2}{*}{ Treatments } & \multicolumn{6}{|c|}{ Anatomic and swimming pattern changes } \\
\hline & Fin rot & Skin ulcer & Damage in gill & Loss of scale & Gasping & Weakness \\
\hline No extract, no pathogen & o & $\circ$ & $\circ$ & o & $\circ$ & o \\
\hline A. paniculata $50 \mu \mathrm{l}$, A. hydrophila & $\checkmark \checkmark$ & $\checkmark \checkmark$ & $\checkmark$ & $\checkmark \checkmark$ & $\checkmark$ & $\checkmark \checkmark$ \\
\hline A. paniculata $100 \mu \mathrm{l}$, A. hydrophila & o & $\checkmark$ & $\checkmark$ & $\checkmark$ & $\checkmark$ & $\checkmark$ \\
\hline A. paniculata $150 \mu \mathrm{l}$, A. hydrophila & o & o & o & o & o & o \\
\hline A. paniculata $200 \mu \mathrm{l}$, A. hydrophila & $\circ$ & $\circ$ & $\circ$ & o & $\circ$ & o \\
\hline No extract only A. hydrophila & $\checkmark \checkmark$ & $\checkmark \checkmark \checkmark$ & $\checkmark \checkmark$ & $\checkmark \checkmark \checkmark$ & $\checkmark \checkmark$ & $\checkmark \checkmark \checkmark$ \\
\hline
\end{tabular}

Normal (০), low $(\checkmark)$, medium $(\checkmark \checkmark)$, high $(\checkmark \checkmark \checkmark)$

et al. 2003; Liu et al. 2007; Umamaheswari and Prince 2007; Kumar et al. 2004). Andrographolide is a bicyclic diterpenoid lactone reported with various immune-modulating properties (Hidalgo et al. 2013; Shamsizadeh et al. 2017).
The health condition of a fish can be measured by analysing their haematological parameters (Cataldi et al. 1998; Sheeba 2012). Hence, the effect of A. paniculata extracts on haematological parameters of healthy and infected
Fig. 7 Cumulative Mortality Rate of (CMR) Rohu in Injection, Oral feeding and Diffusion method. a A. paniculata $50 \mu \mathrm{l}$,

A. hydrophila. b A. paniculata $100 \mu \mathrm{l}$, A. hydrophila. c

A. paniculata $150 \mu \mathrm{l}$, A. hydrophila. d A. paniculata $200 \mu \mathrm{l}$, A. hydrophila

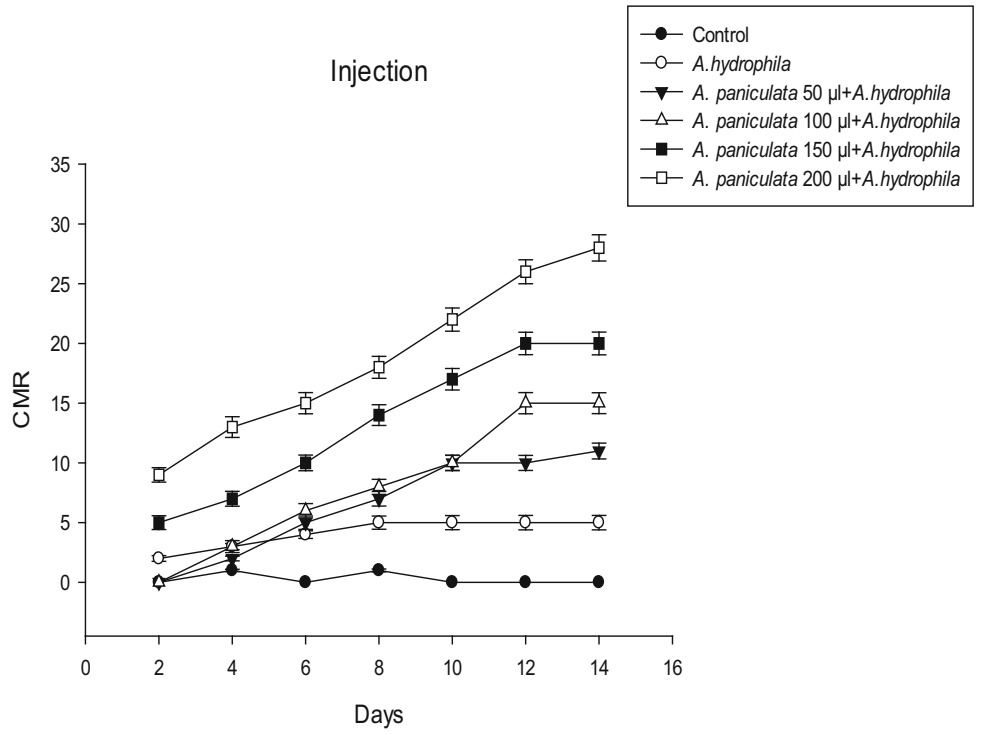

Oral feeding
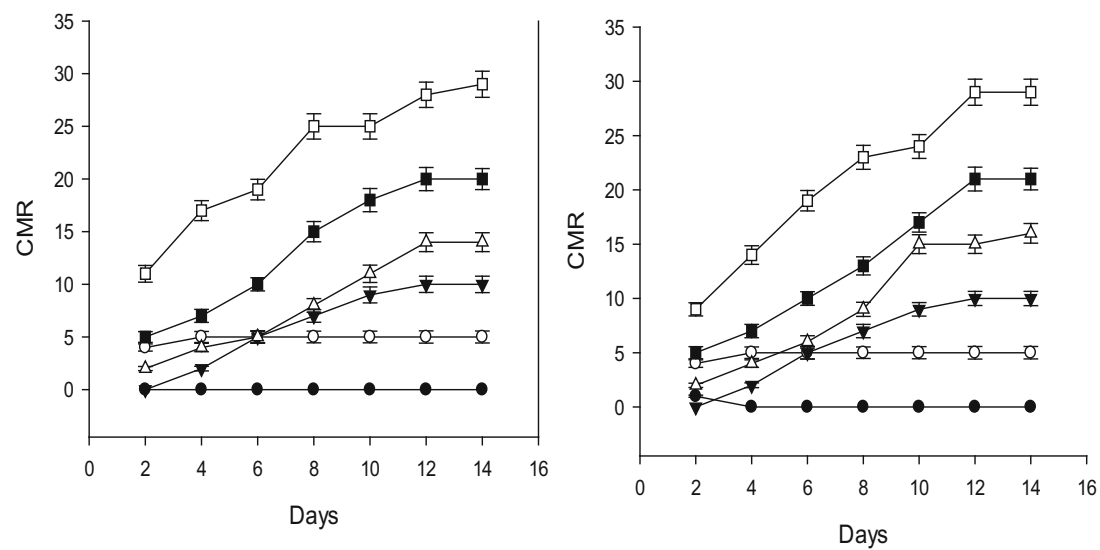
Fig. 8 Cumulative death rate of Rohu in the injection, oral feeding and diffusion methods. a

A. paniculata $50 \mu \mathrm{l}$,

A. hydrophila. b A. paniculata $100 \mu 1$, A. hydrophila. c

A. paniculata $150 \mu \mathrm{l}$, A. hydrophila. d A. paniculata $200 \mu \mathrm{l}$, A. hydrophila

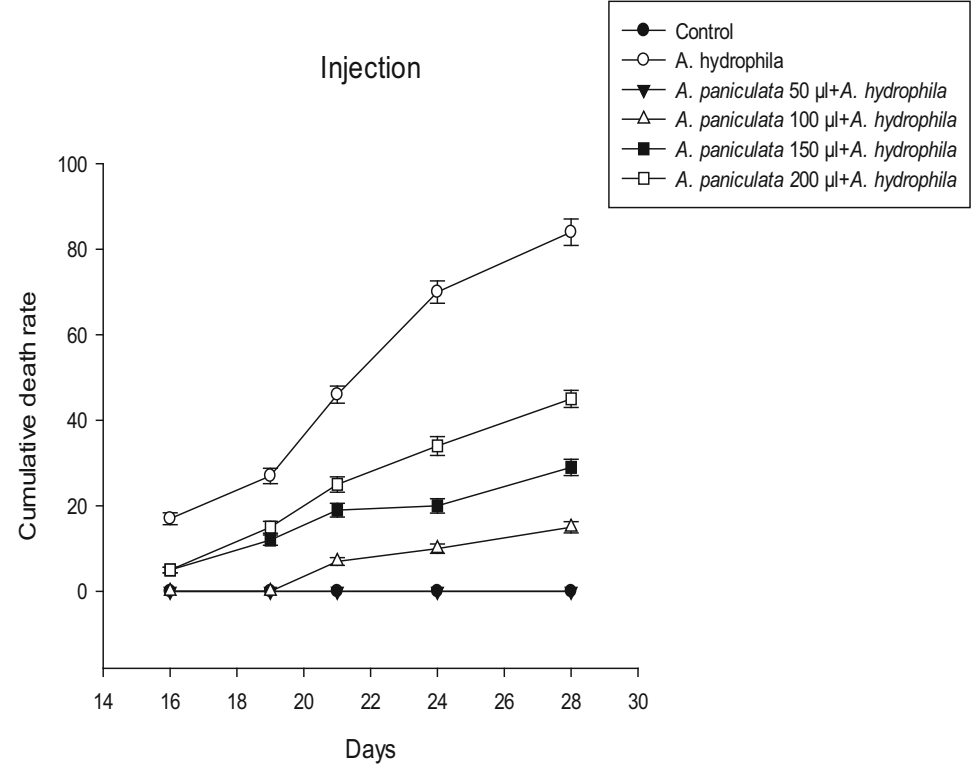

Oral feeding
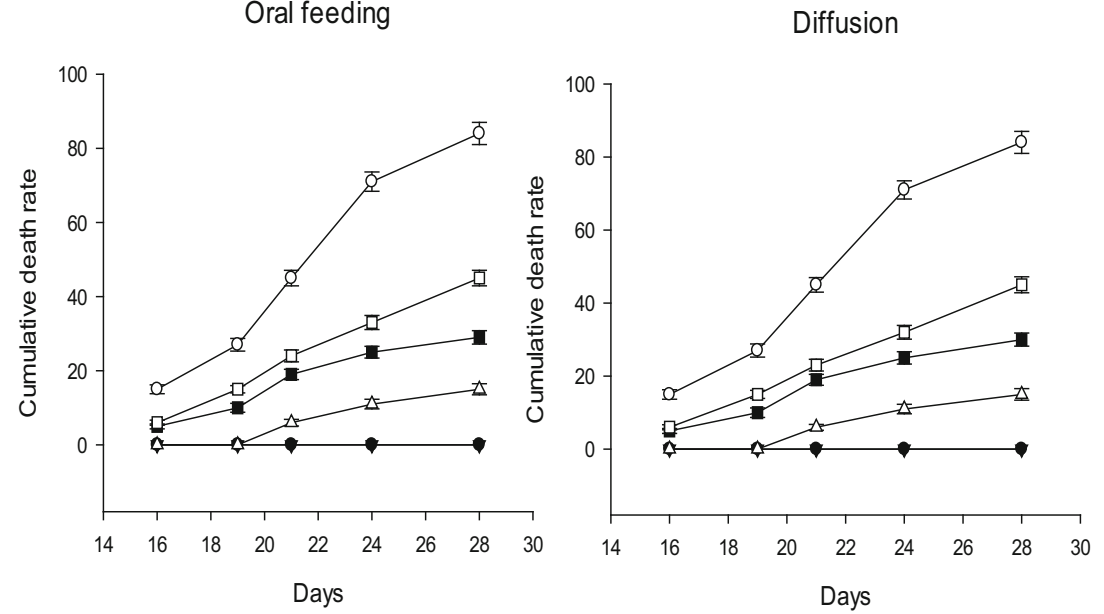

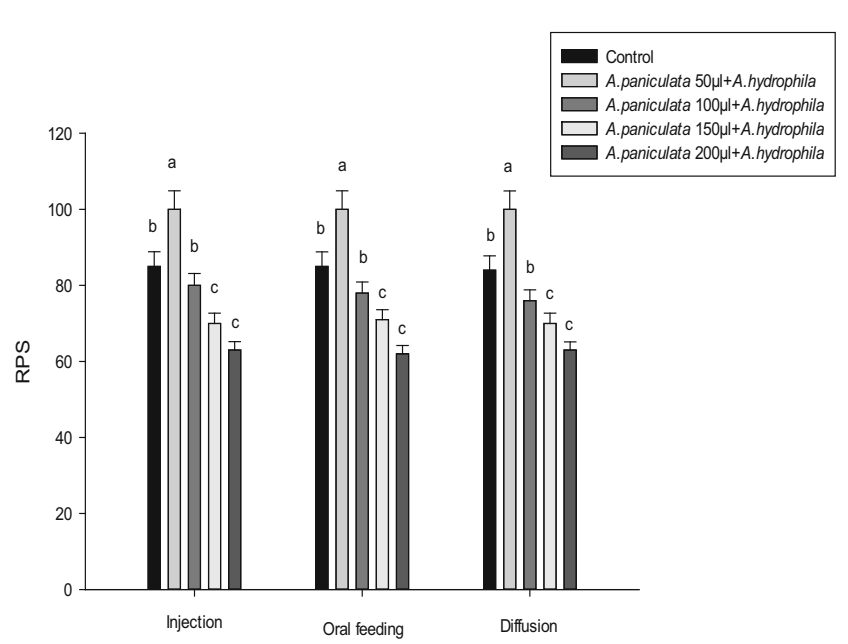

Fig. 9 Relative percentage of survival (RPS) of Rohu in the injection, oral feeding and diffusion methods fish were determined in terms of TEC, TLC and $\mathrm{Hb}$, even though several immunostimulants did not enhance the haematology status of the exposed organism (Harikrishnan et al. 2010). Infection by a pathogen tends to lower the $\mathrm{Hb}$ levels of a fish by the secretion of hemolysin enzyme that degrades RBC resulting in the downfall of TEC and TLC (Sheeba 2012; Hardi et al. 2014). A. paniculata extracts increased the haemoglobin (from 4 to $13.5 \mathrm{~g} \%$ ), erythrocyte (from 22 to $37.9 \times 10^{5}$ cells $\mathrm{mm}^{3}$ ) and leucocyte (from of 2.7 to $4.9 \times 10^{5}$ cells $\mathrm{mm}^{-3}$ ) counts at the end of 28 days that was reduced due to A. hydrophila infection. The upsurge in TEC level might be a result of oxygen transportation then distribution all over the body of the fish caused by the increase in $\mathrm{Hb}$ levels.

The simultaneous increase in TEC corresponds to the increased phagocytosis index of treated infected fish that maximized (62.3\%, injection method) after 28 days. Phagocytic cells (monocyte, neutrophil and lymphocyte) act as immune 
cells by engulfing and destroying the pathogen, and are vital components of the non-specific immune system. The ability of A. paniculata extract to increase the phagocytic index is evidence that the herbal extracts act as immunostimulants (Sahu 2004; Mastan 2015; Pradeepa et al. 2016; SenthilNathan 2013). The potential of A. paniculata extracts to improve the haematology status of the Rohu thus confers disease resistance. As a consequence, this will improve the overall health of the fish (Bridle et al. 2011; Vasantha-Srinivasan et al. 2017a, 2017b; Zokaeifar et al. 2012; Lawhavinit et al. 2011; Alambra et al. 2012).

Three methods, viz. injection, oral feeding and diffusion methods, were chosen as treatment methods. Among them, the injection method proved to be effective by significantly increasing the haematological status of the fish under study. Harikrishnan et al. (2009) showed that the methanol extract of Azadirachta indica, Ocimum santum and Curcuma longa supplemented with the fish feed enhanced the phagocytic index of goldfish 2 weeks after treatment. Christybapita et al. (2007) reported the potential of aqueous extract of Elipta alba leaves to enhance the non-specific immune response in Oreochromis mossambicus and also offering effective disease protection. The phagocytic index will naturally increase upon any pathogenic infection. However, A. hydrophila severely reduced the PI of infected fishes lower enough to affect their survival, leading to $86 \%$ mortality rate. In the meantime, treatment of infected fishes with A. paniculata extracts boosted the phagocytic index of Labeo rohita as early as 7 days after administration. An increase in PI before the onset of disease can provide effective disease resistance capabilities due to the readiness of PI cells to combat the incoming pathogens (Satyantini et al. 2014; Thanigaivel et al. 2017; Senthil-Nathan et al. 2008). This study agreed with the previous report of Logambal et al. (2000), in which the injection of Ocimum sanctum increased the resistance of Oreochromis mossambicus and Carassius auratus against $A$. hydrophila. Similarly, Abutbul (Abutbul et al. 2004) testified that augmentation of fish feed with Rosmarinus officinalis extract promoted the survivability of $A$. hydrophila infected fish. Likewise, Achyranthes extract was also reported to confer increased resistance against $A$. hydrophila infection in Labeo rohita (Joseph and Carnahan 1994; Senthil-Nathan 2007; Vasantha-Srinivasan et al. 2017a, 2017b; Fujiki et al. 1994). Basha et al. (2013) also reported the efficiency of andrographoide to stimulate the non-specific immunity and resistance against $A$. hydrophila in $L$. rohita.

The survival rate of the Labeo rohita supplemented with A. paniculata extracts after A. hydrophila infection was higher than that of the fish supplemented without extract. The methanol of the A. paniculata plant extract effectively increased the performance of the non-specific immunity in L. rohita, constricting the growth of $A$. hydrophila, subsequently increasing their survivability. There was an increase in the cumulative death rate (CDR) of the infected fishes after day 14 and reached a maximum of $85 \%$ on day 28 . Nevertheless, the A. paniculata extract $(50 \mu \mathrm{l})$ was effective in bringing down the CDR to null, thus displaying $100 \%$ relative percentage survival rates in all the methods at the end of 28 days in all the fishes tested. These results indicated that A.paniculata applications effectively increased the phagocytosis index of the fishes, thus inhibiting the growth of A. hydrophila inside the fish.

\section{Conclusion}

The recent study shows the application of plant-based products towards effective and safe disease management is increasing. Additionally, cumulative advantages of these natural products such as being economical, reliable and stable besides the absence of side effects are gaining popularity. This research finally concludes that $A$. paniculata extract can be regarded as a potential immunostimulant that can be effective at very lower concentrations $(50 \mu \mathrm{g} / \mathrm{l})$ against $A$. hydrophila infection. Hence, the use of medicinal plants as a method of treatment in freshwater aquaculture is safe and effective, and can also provide broad-spectrum protection against various infections. Since only limited research has been carried out in the management of $A$. hydrophila infection, our findings might open new dimensions in the application of plant products as effective fish immunostimulants.

Funding information This research was funded by the Department of Biotechnology, Ministry of Science and Technology, grant number BT/ IN/Indo-US/Foldscope//39/2015.

\section{References}

Abdelhamed H, Ibrahim I, Baumgartner W, Lawrence ML, Karsi A (2017) Characterization of histopathological and ultrastructural changes in channel catfish experimentally infected with virulent Aeromonas hydrophila. Front Microbiol 8:1519

Abutbul S, Golan-Goldhirsh A, Barazani O, Zilberg D (2004) Use of Rosmarinus officinalis as a treatment against Streptococcus inane in tilapia (Oreochromis sp.). Aquaculture 238(1-4):97-105

Afifi, WA, and Guerrero LK (2000) Motivations underlying topic avoidance in close relationships. Balancing the secrets of private disclosures $165-180$

Al Laham SA, Al Fadel FM (2014) Antibacterial activity of various plants extracts against antibiotic-resistant Aeromonas hydrophila. Jundishapur J Microb 7(7)

Alain K (2009) Isolation of Aeromonas hydrophila from naturally diseased Thai pangas Pangasius hypophthalmus (doctoral dissertation, MSc thesis, Bangladesh Agricultural University, Mymensingh, Bangladesh)

Alambra JR, Alenton RRR, Gulpeo PCR, Mecenas CL, Miranda AP, Thomas RC, Velando MKS, Vitug LD, Maningas MBB (2012) Immunomodulatory effects of turmeric, Curcuma longa (Magnoliophyta, Zingiberaceae) on macrobrachium rosenbergii 
(Crustacea, Palaemonidae) against Vibrio alginolyticus (Proteobacteria, Vibrionaceae). Aquac Aquarium Conserv Legis 5(1):13-17

Al-Faragi JK, and Alsaphar SA (2012) Isolation and identification of Bacillus subtilis as probiotic from intestinal microflora of common carp Cyprinus carpio L The Iraqi J Vet Intern Med 36(2):355-361

Basha KA, Raman RP, Prasad KP, Kumar K, Nilavan E, Kumar S (2013) Effect of dietary supplemented andrographolide on growth, nonspecific immune parameters and resistance against Aeromonas hydrophila in Labeo rohita (Hamilton). Fish Shellfish Immun 35(5):1433-1441

Ben-David A, Davidson CE (2014) Estimation method for serial dilution experiments. J Microbiol Methods 107:214-221

Béné C, Macfadyen G, and Allison E.H 2007 Increasing the contribution of small-scale fisheries to poverty alleviation and food security (no. 481). Food \& Agriculture Org

Bilen S, Bulut M, Bilen AM (2011) Immunostimulant effects of Cotinus coggyria on rainbow trout (Oncorhynchus mykiss). Fish Shellfish Immun 30(2):451-455

Bilen S, Y1lmaz S, Bilen AM (2013) Influence of tetra (Cotinus coggygria) extract against Vibrio anguillarum infection in koi carp, Cyprinus carpio with reference to haematological and immunological changes. Turk J Fish Aquat Sc 13(3)

Bilen S, Y1lmaz S, Bilen AM, and Biswas G (2014) Effects of dietary incorporation of tetra (Cotinus coggygria) extract on immune response and resistance to Aeromonas hydrophila in koi carp (Cyprinus carpio)

Bilen S, Altunoglu YC, Ulu F, Biswas G (2016a) Innate immune and growth promoting responses to caper (Capparis spinosa) extract in rainbow trout (Oncorhynchus mykiss). Fish \& shellfish immunology $57: 206-212$

Bilen S, Ünal S, Güvensoy H (2016b) Effects of oyster mushroom (Pleurotus ostreatus) and nettle (Urtica dioica) methanolic extracts on immune responses and resistance to Aeromonas hydrophila in rainbow trout (Oncorhynchus mykiss). Aquaculture 454:90-94

Blaxhall PC, Daisley KW (1973) Routine haematological methods for use with fish blood. J Fish Biol 5(6):771-781

Bridle A, Nosworthy E, Polinski M, Nowak B (2011) Evidence of an antimicrobial-immunomodulatory role of Atlantic salmon cathelicidins during infection with Yersinia ruckeri. PLoS One $6(8): 23417$

Cabello FC (2006) Heavy use of prophylactic antibiotics in aquaculture: a growing problem for human and animal health and for the environment. Environ Microbiol 8(7):1137-1144

Cataldi E, Di Marco P, Mandich A, Cataudella S (1998) Serum parameters of Adriatic sturgeon Acipenser naccarii (Pisces: Acipenseriformes): effects of temperature and stress. Comp Biochemistry and Physiology Part A: Mol Integr Physiol 121(4): 351-354

Chao WW, Kuo YH, Lin BF (2010) Anti-inflammatory activity of new compounds from Andrographis paniculata by NF-KB transactivation inhibition. J Agric Food Chem 58(4):2505-2512

Chelladurai G, Veni T, Mohanraj J, Nagarajan R (2017) Effect of herbal extracts supplemented diets on non specific immunity and resistance to Aeromonas hydrophila in Indian cat fish (Mystus montanus). Zool Res 1(1)

Chellappandian M, Vasantha-Srinivasan P, Senthil-Nathan S, Karthi S, Thanigaivel A, Ponsankar A, Kalaivani K, Hunter WB (2018) Botanical essential oils and uses as mosquitocides and repellents against dengue. Environ Int 113:214-230

Christybapita D, Divyagnaneswari M, Michael RD (2007) Oral administration of Eclipta alba leaf aqueous extract enhances the non-specific immune responses and disease resistance of Oreochromis mossambicus. Fish Shellfish Immun 23(4):840-852
Cipriano RC, 2001 Aeromonas hydrophila and motile aeromonad septicemias of fish. US Department of the Interior, J Fish Wildl Manag Washington DC Google Scholar

Cipriano RC, Bullock GL, and Pyle SW (1984) Aeromonas hydrophila and motile aeromonad septicemias of fish

Cuesta A, Meseguer J, Esteban MA (2004) Total serum immunoglobulin $\mathrm{M}$ levels are affected by immunomodulators in seabream (Sparus aurata L.). Vet Immunol Immunopathol 101(3-4):203-210

Devillers J, Steiman R, Seigle-Murandi F (1989) The usefulness of the agar-well diffusion method for assessing chemical toxicity to bacteria and fungi. Chemosphere 19(10-11):1693-1700

Edwin E, Vasantha-Srinivasan P, Senthil-Nathan S, Thanigaivel A, Ponsankar A (2016a) Anti-dengue efficacy of bioactive andrographolide from Andrographis paniculata (Lamiales: Acanthaceae) against the primary dengue vector Aedes aegypti (Diptera: Culicidae). Acta Tropica 163:167-178

Edwin E, Vasantha-Srinivasan P, Senthil-Nathan S, Thanigaivel A et al (2016b) Effect of andrographolide on phosphatases activity and cytotoxicity against Spodoptera litura. Invertebr Surviv J 13:153-163

El-Ghany NAA, and Alla HMLA (2008).A trial for treatment of Ichthyophonosis in cultured Oreochromis niloticus using fucus and neem plants. In 8th International Symposium on Tilapia in Aquaculture Egypt 1329-1349

Elkamel AA, Mosaad GM (2012) Immunomodulation of Nile Tilapia, Oreochromis niloticus, by Nigella sativa and Bacillus subtilis. Aquac Res 3(6)

Ellis AE (ed) (1988) Fish vaccination (no. 4). Academic Press, London

Fang HM, Ge R, Sin YM (2004) Cloning, characterisation and expression of Aeromonas hydrophila major adhesin. Fish Shellfish Immunol 5: $645-658$

FAO (2016) The State of World Fisheries and Aquaculture Opportunities and Challenges

FAO STAT 2012. Main aquaculture countries in 2010. http://www.fao. org/faostat/en/\#home Accessed January, 2018

Fujiki K, Matsuyama H, Yano T (1994) Protective effect of sodium alginates against bacterial infection in common carp, Cyprinus carpio $\mathrm{L}$. J Fish Dis 17(4):349-355

Gobi N, Ramya C, Vaseeharan B, Malaikozhundan B, Vijayakumar S, Murugan K, Benelli G (2016) Oreochromis mossambicus diet supplementation with Psidium guajava leaf extracts enhance growth, immune, antioxidant response and resistance to Aeromonas hydrophila. Fish Shellfish Immunol 58:572-583

Govind P, Madhuri S, and Mandloi AK (2012) Immunostimulant effect of medicinal plants on fish

Hardi JA, and O'Brien III JM, Titan Pet Products Inc (2013) Systems and methods for animal containment, training, and tracking. US Patent 8:438-99

Hardi EH, Pebrianto CA, Hidayanti T, Handayani RT (2014) Infeksi Aeromonas Hydrophila Melalui Jalur Yang Berbeda Pada Ikan Nila (Oreochromis Niloticus) Di Loa Kulu Kutai Kartanegara Kalimantan Timur. J Kedokt Hewan 8(2)

Hardi EH, Kusuma IW, Suwinarti W, Abbas I, and Nugroho RA (2016a) Antibacterial activities of some Borneo plant extracts against pathogenic bacteria of Aeromonas hydrophila and Pseudomonas sp. Aquaculture, Aquarium, Conservation \& Legislation-International AES Bioflux (AACL Bioflux) 9(3)

Hardi EH, Kusuma IW, Suwinarti W, AGUSTINA A, Nugroho RA (2016b) Antibacterial activity of Boesenbergia pandurata, Zingiber zerumbet and Solanum ferox extracts against Aeromonas hydrophila and Pseudomonas sp. Food Biosci 8(1)

Hardi EH, Saptiani G, Kusuma IW, Suwinarti W and Nugroho RA (2017) Immunomodulatory and antibacterial effects of Boesenbergia pandurata, Solanum ferox, and Zingiber zerumbet on tilapia, Oreochromis niloticus. Aquaculture, Aquarium, Conservation \& Legislation- Aes Bioflux (AACL Bioflux) 10(2) 
Harikrishnan R, Balasundaram C (2005) Modern trends in Aeromonas hydrophila disease management with fish. Rev Fish Sci Aquac 13(4):281-320

Harikrishnan R, Balasundaram C, Kim MC, Kim JS, Han YJ, Heo MS (2009) Innate immune response and disease resistance in Carassius auratus by triherbal solvent extracts. Fish Shellfish Immun 27(3): 508-515

Harikrishnan R, Balasundaram C, Heo MS (2010) Herbal supplementation diets on hematology and innate immunity in goldfish against Aeromonas hydrophila. Fish Shellfish Immun 28(2):354-361

Harikrishnan R, Kim JS, Kim MC, Balasundaram C, Heo MS (2011) Lactuca indica extract as feed additive enhances immunological parameters and disease resistance in Epinephelus bruneus to Streptococcus iniae. Aquaculture 318(1-2):43-47

Hidalgo MA, Hancke JL, Bertoglio JC, and Burgos RA (2013) Andrographolide a new potential drug for the long term treatment of rheumatoid arthritis disease. J Rheumatol. Intech

Hidayat Y, Fuad F, Nurhidayati M (2018) Implementation of economic democracy principle in Islamic banking policies through Financial Services Authority (FSA) in Indonesia. At-Taradhi: J Stu Eko 8(2): 132-154

Horne MT, Baxendale A (1983) The adhesion of Vibrio anguillarum to host tissues and its role in pathogenesis. J Fish Dis 6(5):461-471

Joseph SW, Carnahan A (1994) The isolation, identification, and systematics of the motile Aeromonas species. Annual Review of J Fish Dis 4:315-343

Jutti Levita AN, Mutholib A, Ibrahim S (2010) Andrographolide inhibits COX-2 expression in human fibroblast cells due to its interaction with arginine and histidine in cyclooxygenase site. J Appl Sci 10(14): 1481-1484

Kamaraj C, Deepak P, Balasubramani G, Karthi S, Arul D, Aiswarya D, Amutha V, Vimalkumar E, Mathivanan D, Suseem SR, Chanthini KMP, Senthil-Nathan S (2018) Target and non-target toxicity of fern extracts against mosquito vectors and beneficial aquatic organisms. Ecotoxicol Environ Saf 161:221-230

Kanno T, Nakai T, Muroga K (1989) Mode of transmission of vibriosis among ayu Plecoglossus altivelis. J Aquat Anim Health 1(1):2-6

Karina S, Saputri M, and Naufal M (2015) Pemanfaatan ekstrak daun inai (Lawsonia inermis 1.) sebagai bakterisida terhadap Aeromonas hydrophila yang menginfeksi ikan lele sangkuriang (Clarias gariepinus). DEPIK Journal Ilmu-Ilmu Perairan Pesisir dan Perikanan 4(3)

Karina S, Dewiyanti I, Mawardah M (2016) Ekstrak daun Avicennia marina sebagai anti jamur pada telur ikan mas, Cyprinus carpio (Avicennia marina leaf extracts as an anti fungal for common carp, Cyprinus carpio eggs). DEPIK Jurnal Ilmu-Ilmu Perairan Pesisir dan Perikanan 5(3)

Karthi S, Vaideki K, Shivakumar MS, Ponsankar A, Thanigaivel A, Chellappandian M, Vasantha-Srinivasan P, Chanthini KMP, Hunter WB, Senthil-Nathan S (2018) Effect of Aspergillus flavus on the mortality and activity of antioxidant enzymes of Spodoptera litura Fab. (Lepidoptera: Noctuidae) larvae. Pestic Biochem Physiol 149: $54-60$

Kesarcodi-Watson A, Kaspar H, Lategan MJ, Gibson L (2008) Probiotics in aquaculture: the need, principles and mechanisms of action and screening processes. Aquaculture 274(1):1-14

Khamees ES, Al-Rudainy AMJ, Faleh EB (2013) Study of histopathological changes in the common carp (Cyprinus carpio) experimentally infected by bacteria Aeromonas hydrophila. Basrah IJAS 2: 257-268

Kumar RA, Sridevi K, Kumar NV, Nanduri S, Rajagopal S (2004) Anticancer and immunostimulatory compounds from Andrographis paniculata. J Ethnopharmacol 92(2-3):291-295

Kumar IV, Chelladurai G, Veni T, Peeran SSH, Mohanraj J (2014) Medicinal plants as immunostimulants for health management in Indian cat fish. J Coast Life Med 2(6):426-430
Kumar R, Pande V, Singh L, Sharma L, Saxena N, Thakuria D, Singh AK, Sahoo PK (2016) Pathological findings of experimental Aeromonas hydrophila infection in golden mahseer (Tor putitora). Fish Aquac J 7:160

Lategan MJ, Gibson LF (2003) Antagonistic activity of Aeromonas media strain A199 against Saprolegnia sp., an opportunistic pathogen of the eel, Anguilla australis Richardson. J Fish Dis 26(3):147-153

Lawhavinit OA, Sincharoenpokai P, Sunthornandh P (2011) Effects of ethanol turmeric (Curcuma longa Linn.) extract against shrimp pathogenic Vibrio spp. and on growth performance and immune status of white shrimp (Litopenaeus vannamei). Kasetsart J (Nat Sci) 45(1): $70-77$

Lin FL, Wu SJ, Lee SC, Ng LT (2009) Antioxidant, antioedema and analgesic activities of Andrographis paniculata extracts and their active constituent andrographolide. Phytother Res 23(7):958-964

Liu JX, Srivastava R, Che P, Howell SH (2007) An endoplasmic reticulum stress response in Arabidopsis is mediated by proteolytic processing and nuclear relocation of a membrane-associated transcription factor, bZIP28. Plant Cell 19(12):4111-4119

Logambal SM, Venkatalakshmi S, Michael RD (2000) Immunostimulatory effect of leaf extract of Ocimum sanctum Linn. In Oreochromis mossambicus (Peters). Hydrobiologia 430(1-3):113-120

Magnadóttir B (2006) Innate immunity of fish (overview). Fish Shellfish Immun 20(2):137-151

Mahfuzul Hoque MD, Bari ML, Inatsu Y, Juneja VK, and Kawamoto S (2007) Antibacterial activity of guava (Psidium guajava L.) and neem (Azadirachta indica A. Juss.) extracts against foodborne pathogens and spoilage bacteria. Foodborne Pathog Dis 4(4):481-488

Mastan SA (2015) Use of Immunostimulants in aquaculture disease management. Int J Fish Aquat Stud 2:277-280

Menanteau-Ledouble S, Krauss I, Santos G, Fibi S, Weber B, ElMatbouli M (2015) Effect of a phytogenic feed additive on the susceptibility of Onchorhynchus mykiss to Aeromonas salmonicida. Dis Aquat Org 115(1):57-66

Mhaisen FT, Ali AH, Khamees NR (2013) Checklists of monogeneans of freshwater and marine fishes of Basrah province, Iraq. Int J Agr Sci $1: 26-49$

Misra CK, Das BK, Mukherjee SC, Pattnaik P (2006) Effect of multiple injections of $\beta$-glucan on non-specific immune response and disease resistance in Labeo rohita fingerlings. Fish Shellfish Immun 20(3): 305-319

Nahar S, Rahman MM, Ahmed GU, Faruk MR (2016) Isolation, identification, and characterization of Aeromonas hydrophila from juvenile farmed pangasius (Pangasianodon hypophthalmus). Int J Fish Aqu Stud 4(4):52-60

Nandeesha MC, Sentilkumar V, Antony Jesu Prabhu P (2013) Feed management of major carps in India, with special reference to practices adopted in Tamil Nadu. On-farm feeding and feed management in aquaculture. FAO Fish Aquac Tech Pap 583:433-462

Naylor RL, Goldburg RJ, Primavera JH, Kautsky N, Beveridge MC, Clay J, Folke C, Lubchenco J, Mooney H, Troell M (2000) Effect of aquaculture on world fish supplies. Nature 405(6790):1017-1024

Nugroho RA, Fotedar R (2013) Dietary organic selenium improves growth, survival and resistance to Vibrio mimicus in cultured marron, Cherax cainii (Austin, 2002). Fish Shellfish Immun 35(1):7985

Obi CL, Ramalivhana J, Samie A, Igumbor EO (2007) Prevalence, pathogenesis, antibiotic susceptibility profiles, and in-vitro activity of selected medicinal plants against Aeromonas isolates from stool samples of patients in the Venda region of South Africa. J Health Popul Nutr 25(4):428

Palanikani R, Soranam R, Chanthini KMP (2018) Pathogenicity and control of Aeromonas hydrophila and A. veronii in Indian major carps (Catla-catla) by the effect of herbal supplement of 
Andrographis paniculata (Lamiales: Acanthaceae). Inter J Fish Aqu Stud 8, 6(3):361-370

Paniagua C, Rivero O, Anguita J, Naharro G (1990) Pathogenicity factors and virulence for rainbow trout (Salmo gairdneri) of motile Aeromonas spp. isolated from a river. J Clin Microbiol Infect 28(2):350-355

Ponsankar A, Sahayaraj K, Senthil-Nathan S, Vasantha-Srinivasan P, Karthi S, Thanigaivel A et al (2019) Toxicity and developmental effect of Cucurbitacin E from Citrullus colocynthis L. (Cucurbitales: Cucurbitaceae) against Spodoptera litura Fab. and a non-target earthworm Eisenia fetida Savigny. Environ Sci Pollut Res. https://doi.org/10.1007/s11356-019-04438-1

Pradeepa V, Senthil-Nathan S, Sathish-Narayanan S, Selin-Rani S (2016) Potential mode of action of a novel plumbagin as a mosquito repellent against the malarial vector Anopheles stephensi, (Culicidae: Diptera). Pestic Biochem Physiol 134:84-93

Quesada SP, Paschoal JAR, Reyes FGR (2013) Considerations on the aquaculture development and on the use of veterinary drugs: special issue for fluoroquinolones - a review. J Food Sci 78(9):R1321R1333

Rajani M, Shrivastava N, Ravishankara MN (2000) A rapid method for isolation of andrographolide from Andrographis paniculata Nees (Kalmegh). Pharm Biol 38(3):204-209

Ramena G, Ramena Y, Challa N (2018) Identification and Determination of Minimum Inhibitory Concentrations of Plant Extracts having Antimicrobial Activity as Potential Alternative Therapeutics to Treat Aeromonas hydrophila. Infections J Microb Path 2:104

Ratnawati D, Martono A, Fitriyanti W (2013) Study on the potency of methanol extracts from Xanthosoma nigrum stellfeld as natural antioxidant by thiobarbituric acid method. Aceh International 2(3)

Richardson K, Steffen W, and Liverman D, eds (2011) Climate change: global risks, challenges and decisions. Cambridge University Press

Roberts RJ, Rodger HD (2012) The pathophysiology and systematic pathology of teleosts. Fish Pathol:62-143

Sahu S (2004) Antibacterial activity of plant extracts on fish microbial pathogens, MF Sc (Doctoral dissertation, Dissertation thesis, CIFA, Kausalyaganga, Bhubaneswar, India)

Saptiani G, Hardi EH, Pebrianto CA, and Ardhani F (2016a) Alpinia galanga extracts for improving egg hatchability and larval viability of catfish. In AIP Conference Proceedings (Vol. 1755, No. 1, p. 140002) AIP Publishing

Saptiani G, Hardi EH, Pebrianto CA, Agustina AF, Ardhani F (2016b) Antimicrobial potential of Carica papaya, Ipomoea aquatica, Alpinia galanga and Piper betle against the aquatic microbials. Nusantara Biosci 8(2):252-257

Satyantini WH, Harris E, Utomo NBP (2014) Administration of Spirulina phycocyanin enhances blood cells, phagocytic activity and growth in humpback grouper juvenile. J Vet Dent 15(1):46-56

Senthil-Nathan S (2007) The use of Eucalyptus leaf extract as a natural larvicidal agent against malarial vector Anopheles stephensi Liston (Diptera: Culicidae). Bioresour Technol 98(9):1856-1860

Senthil-Nathan S (2013) Physiological and biochemical effect of neem and other Meliaceae plants secondary metabolites against lepidopteran insects. Front Physiol 4(359):1-17

Senthil-Nathan S (2015) A review of biopesticides and their mode of action against insect pests.In: Environmental Sustainability- Role of Green Technologies, Springer-Verlag, 49-63

Senthil-Nathan S, Kalaivani K, Murugan K (2005) Effects of neem limonoids on the malaria vector Anopheles stephensi Liston (Diptera: Culicidae). Acta Trop 96(1):47-55

Senthil-Nathan S, Hisham A, Jayakumar G (2008) Larvicidal and growth inhibition of the malaria vector Anopheles stephensi by triterpens from Dysoxylum spp. (Meliaceae). Fitoterapia 76:106-111

Shamsizadeh A, Roohbakhsh A, Ayoobi F, and Moghaddamahmadi A (2017) The role of natural products in the prevention and treatment of multiple sclerosis. In Nutrition and Lifestyle in Neurological Autoimmune Diseases 249-260

Shankar KM, Mohan CV, Anil TM, Vidhya R (2000) Monoclonal antibodies in fish and shellfish health management in India. Naga, International Center for Living Aquatic Resources Managemen 23(4):10-12

Sheeba S (2012) Effect of oral immunostimulant Andrographis paniculata and resistance to Aeromonas hydrophila in Catla catla. IJRAP 3(2): $1-5$

Snedecor GWC, and William G (1989) statistical methods/George w. Snedecor and William g. Cochran (No. QA276. 12. S6313 1989)

Stratev D, Stoev S, Vashin I, Daskalov H (2015) Some varieties of pathological changes in experimental infection of carps (Cyprinus carpio) with Aeromonas hydrophila. J Aquacult Eng Fish Res 1(4):191-202

Tajuddin SA, Tariq M (1983) Anti-inflammatory activity of Andrographis paniculata Nees (Chirayata). Nagarjun 27:13-14

Tan Y, Chiow KH, Huang D, Wong SH (2010) Andrographolide regulates epidermal growth factor receptor and transferrin receptor trafficking in epidermoid carcinoma (A-431) cells. Br J Pharmacol 159(7):1497-1510

Thanigaivel A, Senthil-Nathan S, Vasantha-Srinivasan P, Edwin ES, Ponsankar A, Selin-Rani S, Pradeepa V, Chellappandian M, Kalaivani K, Abdel-Megeed A, Narayanan R, Murugan K (2017) Chemicals isolated from Justicia adhatoda Linn reduce fitness of the mosquito, Aedes aegypti L. Arch Insect Biochem Physiol 94(4): e21384

Umamaheswari S, and Prince PSM (2007) Antihyperglycaemic effect of ëilogen-excelí, an ayurvedic herbal formulation in streptozotocininduced diabetes mellitus

Vasantha-Srinivasan P, Senthil-Nathan S, Ponsankar A, Thanigaivel A, Edwin ES, Selin-Rani S, Chellappandian M, Pradeepa V, LijaEscaline J, Kalaivani K, Hunter WB, Duraipandiyan V, al-Dhabi NA (2017a) Comparative analysis of mosquito (Diptera: Culicidae: Aedes aegypti Liston) responses to the insecticide Temephos and plant derived essential oil derived from Piper betle L. Ecotoxicol Environ Saf 139:439-446

Vasantha-Srinivasan P, Senthil-Nathan S, Ponsankar A, Thanigaivel A, Chellappandian M, Edwin ES et al (2017b) Acute toxicity of chemical pesticides and plant-derived essential oil on the behavior and development of earthworms, Eudrilus eugeniae (Kinberg) and Eisenia fetida (Savigny). Environ Sci Pollut Res:1-12

Vasantha-Srinivasan P, Chellappandian M, Senthil-Nathan S, Ponsankar A, Thanigaivel A, Karthi S et al (2019a) A novel herbal product based on Piper betle and Sphaeranthus indicus essential oils: toxicity, repellent activity and impact on detoxifying enzymes GST and CYP450 of Aedes aegypti Liston (Diptera: Culicidae). J AsiaPacific Entomol 21(4):1466-1472

Vasantha-Srinivasan P, Karthi S, Chellappandian S, Ponsankar A, Thanigaivel A, Senthil-Nathan S, Chandramohan D, Ganesan R (2019b) Aspergillus flavus (Link) toxins reduces the fitness of dengue vector Aedes aegypti (Linn.) and their non-target toxicity against aquatic predator. Microb Pathog 128:281-287

Venkatalakshmi S, Michael RD (2001) Immunostimulation by leaf extract of Ocimum sanctum Linn. in Oreochromis mossambicus (Peters). J Aquacult Trop 16(1):1-10

Vivekanandhan P, Senthil-Nathan S, and Shivakumar MS (2018a) Larvicidal, pupicidal and adult smoke toxic effects of Acanthospermum hispidum (DC) leaf crude extracts against mosquito vectors. Physiol Mol Plant Path 101(3):156-162

Vivekanandhan P, Venkatesan R, Ramkumar G, Karthi S, Senthil-Nathan S, Shivakumar MS (2018b) Comparative analysis of major mosquito vectors response to seed-derived essential oil and seed podderived extract from Acacia nilotica. Int J Environ Res Public Health 15(2):388 
Wang L, Weller CL (2006) Recent advances in extraction of nutraceuticals from plants. Trends Food Sci Technol 17(6):300-312

Wang W, Wang J, Dong SF, Liu CH, Italiani P, Sun SHXJ, Boraschi D, Ma SP, Qu D (2010) Immunomodulatory activity of andrographolide on macrophage activation and specific antibody response. Acta Pharmacol Sin 31(2):191-201

Wedemeyer GA, and Yasutake WT (1977) Clinical methods for the assessment of the effects of environmental stress on fish health (no. 89). USFWS

$\mathrm{Xu}$ Y, Marshall RL, Mukkur TK (2006) An investigation on the antimicrobial activity of Andrographis paniculata extracts and andrographolide in vitro. Asian J Plant Sci 5:527-530

Yambot AV, and Inglis V (1994)Aeromonas hydrophila from Nile tilapia (Orerochromis niloticus L.)with eye disease. International Congress on Quality Veterinary Services for the 21st Century, Kuala Lumpur 87-89

Yin G, Ardó LÁSZLÓ, Thompson KD, Adams A, Jeney Z, Jeney G (2009) Chinese herbs (Astragalus radix and Ganoderma lucidum) enhance immune response of carp, Cyprinus carpio, and protection against Aeromonas hydrophila. Fish Shellfish Immunol 26(1):140145

Yu BC, Chen WC, Cheng JT (2003) Antihyperglycemic effect of andrographolide in streptozotocin-induced diabetic rats. Planta Med 69(12):1075-1079

Zhang Z, Jiang J, Yu P, Zeng X, Larrick JW, Wang Y (2009) Hypoglycemic and beta cell protective effects of andrographolide analogue for diabetes treatment. J Transl Med 7(1):62

Zhou J, Ong CN, Hur GM, Shen HM (2010) Inhibition of the JAKSTAT3 pathway by andrographolide enhances chemosensitivity of cancer cells to doxorubicin. Biochem Pharmacol 79(9):1242-1250

Zokaeifar H, Balcázar JL, Saad CR, Kamarudin MS, Sijam K, Arshad A, Nejat N (2012) Effects of Bacillus subtilis on the growth performance, digestive enzymes, immune gene expression and disease resistance of white shrimp, Litopenaeus vannamei. Fish Shellfish Immunol 33(4):683-689

Publisher's note Springer Nature remains neutral with regard to jurisdictional claims in published maps and institutional affiliations. 